\title{
Skills in Geography and Economics Reflected in Austria's Newly Developed Key Concepts and Competencies for the 2023/24 Curriculum
}

\author{
Christian FRIDRICH ${ }^{1}$ \\ Vienna University of Teacher Education, Vienna AUSTRIA
}

1Prof. Dr. Christian Fridrich, Vienna University of Teacher Education, Institute for General Education in Secondary Education, Department of Geographical and Socio-Economic Education, Vienna, AUSTRIA. christian.fridrich [at] phwien.ac.at. ORCID:

\begin{abstract}
The Austrian school subject Geography and Economics is taught throughout lower secondary level (grades 5 to 8 ). Following three subject-related didactic paradigm shifts since 1962, it has developed into an integrated, sociallyoriented subject in the social sciences tradition, and focuses on the person acting spatially and economically in social contexts. The central research question is: How can the goal of the subject of Geography and Economics, which is to enable young people to act in the "society-economy-politics-environment" framework, be pursued and supported at curricular level? In a Vienna-wide study $(n=527)$, assessments made of Geography and Economics teachers in respect of their teaching of the subject were collected in a triangulation design, using a questionnaire with open and closed questions. The evaluation of their responses used a mixed methodology of inductive category formation within the framework of qualitative content analysis (Mayring, 2000), as well as variance analyses and significance tests. At the centre of their teaching, teachers place the acquisition of knowledge, the human being acting in spatial, societal and economic contexts and man-environment systems, or precisely described skills; statistical correlations between teachers' years of service and level of education become apparent. The perception of the degree of integration of the two areas of Geography and Economics depends, among other things, on the teachers' attitude towards the economy. While the teachers' assessment of Geography and Economics as an integrated or combined subject is appropriate, the integration in the classroom could be further developed. For the new 2023/24 curriculum, integrated competenceoriented learning objectives and integrated key concepts were generated on the empirical basis of our results, and on the basis of subject-related didactic considerations and principles. This should further deepen the integration of geography and economics perspectives and how their integration is achieved in the classroom.
\end{abstract}

\section{Keywords}

Skills, Areas Of Competence; Learning Goals; Geography And Economics; Mixed-Method Design

To cite this article: Fridrich, C. (2021). Skills in geography and economics reflected in austria's newly developed key concepts and competencies for the 2023/24 curriculum. Review of International Geographical Education (RIGEO), 11(2), 335-371. doi: 10.33403rigeo.839619 
The School Organization Act of 1962 created the subject of Geography and Economics from the single subject Geography, which became today's integrated subject only after three paradigm shifts. Anchoring economics education in this subject introduced the integrative treatment of human geography, and social, political and ecological issues, an integration which has been deepened over time. Society and the economy are understood as being shaped by people, and young people (school students) thus see themselves as being able to shape society and the economy. Physical geography comes into play when working on humanenvironment systems, for example in examining ecological questions such as climate change, global change, changes in habitats, etc.

For decades, Geography and Economics has been part of the curriculum of all classes in lower secondary education (grades 5 to 8), and this will continue to be the case. In addition, the subject is represented throughout the upper secondary level (grades 9 to 12) at Gymnasium ${ }^{1}$, as well as in individual classes of various technical and vocational schools and colleges (grades 9 to 13). This paper focuses exclusively on Geography and Economics at lower secondary level. At the center of this combined (dual, side-by-side) and integrated (intertwined) subject (see Table 1) is the person acting spatially and economically in social contexts. Young people should therefore not only be able to understand, analyse and evaluate the "societyeconomy-politics-environment" structure (Curriculum Group GW, 2020, p. 2), but above all become capable of acting within it.

The central research question to which this contribution is devoted is:

- How can the goal of the subject of Geography and Economics, which is to enable young people to act in the "society-economy-politics-environment" framework, be pursued and supported at curricular level?

This question was and is of great relevance, especially in that it plays an important role in the redesign of the curriculum for Geography and Economics. This curriculum became available in a very advanced draft in autumn 2020, and will be presented here mainly in terms of key concepts and competences.

The contribution is structured as follows. For a better understanding of the contexts, the next section presents perspectives and paradigm shifts in the school subject Geography and Economics in Austria, while the subsequent section deals with subject-relevant didactic concepts.

Based on the central research question stated above, three further research questions were formulated to gain an insight into how the subject Geography and Economics is currently being implemented by teachers:

1. What concept do teachers put at the heart of their Geography and Economics lessons?

\footnotetext{
${ }^{1}$ Gymnasium is a secondary school that is specifically for more "academic" students.
} 
2. To what extent do teachers of Geography and Economics perceive Geography and Economics as combined subjects, or as being integrated, or as having no relationship to each other?

3. To what extent is Geography and Economics taught in an integrated manner?

A further section presents the methodology of the study; empirical results concerning the research question are then set out in the subsequent section. Together with the specifications of the Austrian Ministry of Education, the empirical results and the didactic reflections lead to considerations of the key concepts and competences of the new curriculum, which was designed by a group of didacticians. Finally, the results are discussed and implementations given.

\section{Perspectives and Paradigm Shifts in the School Subject Geography and Economics İn Austria}

To contextualize the subject of this contribution for readers, the numerous efforts to improve, and the lines of development of, Geography and Economics as a subject are presented in five phases and three paradigm shifts (for detailed explanations, see C. Sitte, 1989; W. Sitte, 2001; C. Sitte, 2001; Fridrich, 2018). Table 1 serves as an introductory overview. 
Table 1

Keyword Overview Of Increasing Integration, And The Sequence Of Phases, Paradigms And Principles In Geography And Economics (Source: Own Presentation Based On Text Sources By W. Sitte, 2001, Pp. 158ff.; C. Sitte, 2001, Pp. 223-224; Curriculum Group GW, 2020)

\begin{tabular}{|c|c|c|c|c|c|}
\hline $\begin{array}{l}\text { Level of } \\
\text { integra- } \\
\text { tionl }\end{array}$ & Paradigm & Year & $\begin{array}{l}\text { Predominant } \\
\text { approach }\end{array}$ & Predominant principles & $\begin{array}{l}\text { Central } \\
\text { aspect }\end{array}$ \\
\hline \multirow[t]{2}{*}{\begin{tabular}{l|l|}
$n$ & \\
0 & \\
$E$ & \\
0 \\
E \\
0 \\
0
\end{tabular}} & $\begin{array}{l}\text { Phase 5: } \\
\text { Geography and } \\
\text { Economics as an } \\
\text { integrated } \\
\text { subject }\end{array}$ & $\begin{array}{l}\text { from } \\
2023 / 24\end{array}$ & $\begin{array}{l}\text { Competence- } \\
\text { oriented, } \\
\text { promoting } \\
\text { competences } \\
\text { and structuring } \\
\text { them into } \\
\text { distinct areas, } \\
\text { systematically } \\
\text { building up } \\
\text { from the simple } \\
\text { to the complex }\end{array}$ & $\begin{array}{l}\text { - Focus on the human being in } \\
\text { the interplay of society- } \\
\text { economy-politics-environment } \\
\text { - Integration of geography and } \\
\text { economics education through } \\
\text { the concept of action } \\
\text { - Systematic integration of } \\
\text { household, consumer, labour } \\
\text { and social economy } \\
\text { - Competence model } \\
\text { - Central subject concepts } \\
\text { - Contributions to economics, } \\
\text { political, informatics, lapoguage } \\
\text { and ecological education, as } \\
\text { well as entrepreneurship } \\
\text { education } \\
\text { - Framework character }\end{array}$ & $\begin{array}{l}\text { Responsible } \\
\text { human } \\
\text { beings in } \\
\text { society, the } \\
\text { economy, } \\
\text { politics and } \\
\text { the } \\
\text { environment, } \\
\text { in spatial and } \\
\text { temporal } \\
\text { contexts }\end{array}$ \\
\hline & \multicolumn{5}{|c|}{ Paradigm shift C: further internal structural change through curriculum reform 2023/24 } \\
\hline 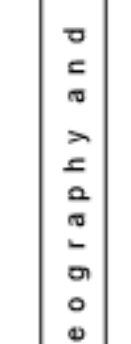 & $\begin{array}{l}\text { Phase 4: } \\
\text { Geography and } \\
\text { Economics as a } \\
\text { combined or } \\
\text { integrated } \\
\text { subject }\end{array}$ & $\begin{array}{l}2000- \\
2023 / 24\end{array}$ & $\begin{array}{l}\text { Goal-oriented, } \\
\text { thematically } \\
\text { structured, } \\
\text { from the simple } \\
\text { to the complex }\end{array}$ & $\begin{array}{l}\text { In addition to the } 1985 / 86 \\
\text { curriculum: } \\
\text { - Objectives without learning } \\
\text { content } \\
\text { - Core and extension areas } \\
\text { - Reduction in number of topics } \\
\text { and objectives } \\
\text { - Contributions to the education } \\
\text { domain }\end{array}$ & $\begin{array}{l}\text { Human } \\
\text { beings, } \\
\text { and spatial } \\
\text { and } \\
\text { economic } \\
\text { aspects of } \\
\text { human action }\end{array}$ \\
\hline $\begin{array}{l}0 \\
- \\
0 \\
= \\
\frac{\pi}{0}\end{array}$ & $\begin{array}{l}\text { Phase } 3 \text { : } \\
\text { Geography and } \\
\text { Economics as a } \\
\text { combined or } \\
\text { integrated } \\
\text { subject }\end{array}$ & $\begin{array}{l}1985 / 86 \\
-2000\end{array}$ & $\begin{array}{l}\text { Goal-oriented, } \\
\text { thematically } \\
\text { structured, } \\
\text { from the simple } \\
\text { to the complex }\end{array}$ & $\begin{array}{l}\text { - Focus on the human dimension } \\
\text { - Integration of Geography and } \\
\text { Economics via the concept of } \\
\text { action } \\
\text { - Thematic structure } \\
\text { - Framework character }\end{array}$ & $\begin{array}{l}\text { Human } \\
\text { beings, } \\
\text { and spatial } \\
\text { and } \\
\text { economic } \\
\text { aspects of } \\
\text { human action }\end{array}$ \\
\hline ar & \multicolumn{5}{|c|}{ Paradigm shift B: internal structural change through curriculum reform 1985/86 } \\
\hline $\begin{array}{l}\stackrel{ \pm}{c} \\
\bar{c} \\
\text { an } \\
\frac{\pi}{\text { on }} \\
\text { in }\end{array}$ & $\begin{array}{l}\text { Phase 2: } \\
\text { Traditional } \\
\text { regional studies } \\
\text { with economics }\end{array}$ & $\begin{array}{l}1962- \\
1985 / 86\end{array}$ & Description & $\begin{array}{l}\text { - Integration of economics into } \\
\text { school geography } \\
\text { - Economics to complement } \\
\text { traditional regional studies } \\
\text { - School pilot studies at lower } \\
\text { secondary level with thematic } \\
\text { focus and objectives }\end{array}$ & $\begin{array}{l}\text { States and } \\
\text { landscapes } \\
\text { in } \\
\text { combination } \\
\text { with } \\
\text { economic } \\
\text { facts }\end{array}$ \\
\hline$\stackrel{0}{2}$ & \multicolumn{5}{|c|}{ Paradigm shift A: external structural change through the School Organization Act 1962} \\
\hline $\begin{array}{l}0 \\
=\end{array}$ & $\begin{array}{l}\text { Phase 1: } \\
\text { Traditional } \\
\text { regional studies }\end{array}$ & $\begin{array}{l}19 \text { th } \\
\text { century } \\
\text { to } 1962\end{array}$ & Description & $\begin{array}{l}\text { - Knowledge about Austria and } \\
\text { the world } \\
\text { - Natural phenomena, population, } \\
\text { the economy } \\
\text { - From near to far in "concentric } \\
\text { circles" } \\
\text { - Traditional regional studies }\end{array}$ & $\begin{array}{l}\text { States and } \\
\text { landscapes }\end{array}$ \\
\hline
\end{tabular}


The first phase, which lasted until 1962, is dominated by traditional regional studies, in which geography and economics topics are dealt with cumulatively, focusing on a series of individual states. A descriptive approach dominates, in which states are understood as "container spaces", which are always treated according to the same sequence: natural conditions, human geography, and finally economics topics. The paradigm is described by a subject didactician as follows: "For decades, the main task of Geography/geography lessons was to provide young people with orientation knowledge of the earth in the form of a more or less topographically rich study of states and countries" (W. Sitte, 1975, p. 11). In this phase of school geography, the teaching of data and facts about states, and their reproduction by learners (in tests, for example) are clearly at the center of the lessons. In addition, the use of maps and map-related representations (globes, models of landforms etc.) is practised.

The School Organization Act of 1962 brought about paradigm shift A, an external change in the subject's structure, by turning the subject Geography into Geography and Economics. The reason for this was the greater economization of society, which was to be reflected in additional education but without creating a new subject or fragmenting the timetable into small one-hour/week subjects. This development was just as far-sighted as the conscious decision to teach economics not according to component systems within the economy (such as business administration or national economics), but as a contribution to increasing young people's understanding of economics more broadly (W. Sitte, 2001, p. 160; Fridrich, 2018, p. 84).

In Phase 2, which lasted from 1962 to 1985, geography topics were increasingly supplemented by economics topics within traditional regional studies. In some cases, this meant a combined economics-and-geography approach, but in other cases, selected economics topics such as supply, demand, price, money, etc. were added to the study of particular countries, at appropriate places. Experienced didacticians, however, soon doubted whether this addition was a good way of adequately developing understanding of spatial, social and economic structures and processes. The following conclusion of a subject didactic analysis exemplifies this: "Today, the development of the subject and of the subject's didactics require a new concept for our subject [...]: the concept of a thematically structured and learning goal-oriented teaching which integrates spatial and economic questions of the present and future and considers them from a political point of view" (W. Sitte, 1975, p. 43, emphasis in original). There were further objections to traditional regional studies (which could not be taught according to the exemplary principle just quoted), to methodologies that emphasized the acquisition of competences (Schultze, 1996, 27), and to constructivist approaches, such as the design of subjective worldviews (see Daum \& Werlen, 2001, p. 9; for further detailed discussion, see also Fridrich, 2013, p. 18ff.). In this phase of traditional regional studies on to which economics had been added and which was based on a descriptive approach, the focus was not on skills, abilities or even competences, but 
rather on imparting and acquiring knowledge, and finding one's way around cartographic representations.

Paradigm shift B brought about a structural change within the subject and was introduced by a curriculum reform, implemented initially in the $5^{\text {th }}$ grade in the $1985 / 86$ school year, and then up to the $12^{\text {th }}$ grade. The two fields of Geography and Economics were combined and integrated with each other by means of a sociallyoriented concept: action. The paradigm now focused on the human being acting spatially and economically within social contexts (W. Sitte, 2001, p. 164).

In phase 3, which lasted from 1985/86 to 2000, an internal structural change took place: a move away from a descriptive approach in which individual states were at the forefront, towards a learning goal-oriented, thematically-structured approach that was ordered according to increasing complexity. At the learningobjective level in particular, the focus was no longer only on knowledge transfer (in a "jug and mug" approach), but also on developing students' subject-specific skills and understanding, including analysis and interpretation, using subject-related methods.

Competence development is not usually addressed explicitly in this phase, but often resonates implicitly. In any case, the focus of teaching Geography and Economics is no longer on "space" but on the acting human being. Evidence for this shift in emphasis can also be found in the literature of the science (as opposed to the pedagogy) of human geography. Werlen (1995), for example, discusses social geography, stating that social conditions cannot be adequately grasped using approaches that consider space as something absolute (p. 76), and that "space problems" are essentially to be understood as action problems, because, for example, material space hinders the achievement of action goals or execution of action (Werlen, 1997, p. 392), or - conversely - promotes them. For example, local topography may favour or hinder the construction of infrastructure. It is thus clear that "spatiality is an immanent aspect of socio-economic systems. Spatiality is a constituent part of socio-economic-systems" (Weichhart, 1996, p. 41). In this early phase of Geography and Economics as a combined subject, the descriptive teaching approach is being replaced by a learning goal-oriented system with topics of increasing complexity.

A further modest development of the curriculum for lower secondary level (grades 5 to 8), which took place in 2000, continued the idea of the paradigm shift of 1985/86 in phase 4 of the combined and integrated subject. The following analysis of the curriculum is intended to clarify to what extent and how many geography and economics objectives were combined in the curriculum, and to document the way and number of times geography and economics objectives were integrated with each other. The objectives of the curriculum are generally formulated in a complex way and leave room for interpretation. An example of a predominantly geographical curriculum objective for the $5^{\text {th }}$ grade would be: "To grasp that there is regularity in the locations of climatic phenomena on earth" (BMB, 
Fridrich, C. (2021). Skills in geography and economics reflected in austria's newly developed key...

2000, p. 3). An exemplary learning objective which can be assigned predominantly to the field of economics is: "Recognising the basic structures of simple economic forms: from the agrarian-dominated self-sufficiency economy to systems based on the division of labour" (ibid.). In many learning objectives, however, an integrative view of Geography and Economics is expressed, as in this one from the beginning of the $5^{\text {th }}$ grade: "Recognizing that people adjust their living and consumption habits to regional and cultural conditions and that lifestyles are subject to change."

An analysis of the stated learning objectives and counting them produces the following results (see Figure 1).

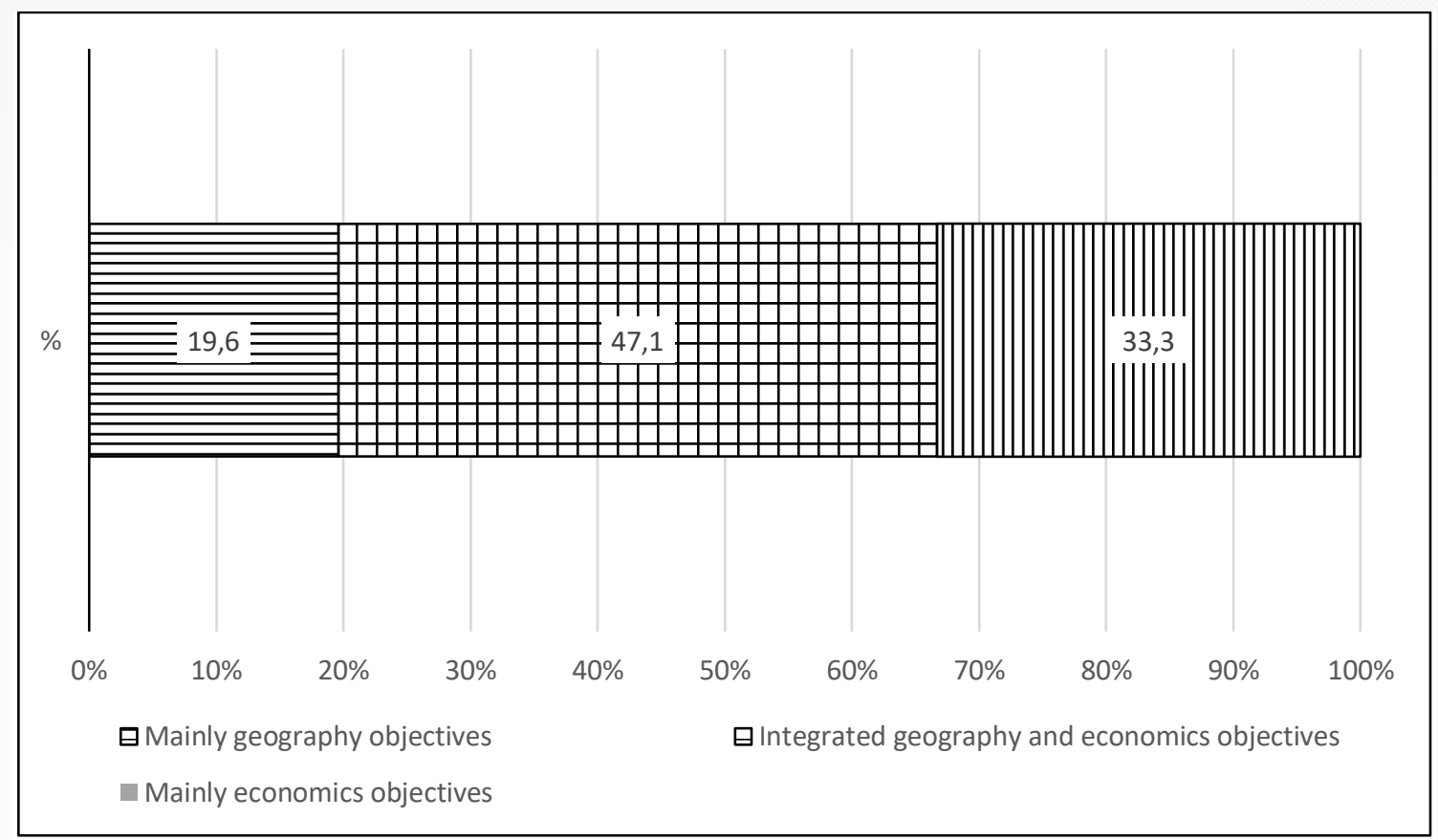

Figure 1. Percentages of the mainly geography, the mainly economics, and the integrated geography and economics objectives of the 2000 curriculum for lower secondary level education in Geography and Economics (Source: own calculation and presentation by Christian Fridrich)

The importance of learning objectives increased with Curriculum 2000 because learning content was no longer specified in the curriculum. At the time, discussion of 'competence' was in its early stages, and the operators used within the curriculum objectives are not for the most part competence-oriented; rather, they use verbs such as 'to recognize', 'to grasp', 'to acquire', 'to comprehend' and 'to gain insight'. In rare cases only, curriculum goals contain competence-oriented operators, such as planning, elaborating, evaluating, assessing, examining and comparing. In this (current) phase, the curriculum of upper secondary level (grades 9 to 12) 2016 has been revised in a competence-oriented way, and at the same time 13 key concepts have been introduced (Hinsch et al., 2014, p. 51). Overlapping with the implementation of the Geography and Economics curriculum for upper secondary level 2016, subject-related didactic discussions will be held on new overarching 
objectives, key concepts, competences and socio-economics education, which will find expression in the paradigm shift of the new curriculum 2023/24.

\section{Subject-Specific Didactic Concepts As a Basis for The 2023/24 Curriculum}

Concepts which are increasingly being discussed in general didactics and in the didactics of Geography and Economics since around the beginning of the $21^{\text {st }}$ century are 'competence orientation', 'key concepts' and 'socio-economics education'. These three central concepts are now being discussed as the basis of the new curriculum, for which they are highly relevant.

\section{Competence Orientation}

With regard to competence orientation, there has been and there continues to be extensive didactic discussion derived from general didactic discourse, with authors being both for and against (see e.g. Bohlinger, 2007; Vielhaber, 2008; Sander, 2010; Dickel, 2011; Rhode-Jüchtern, 2011; Reusser, 2014; Fritz et al., 2019; Greiner et al., 2020). For reasons of space, we cannot even begin to summarize this discussion here adequately. Rather, those starting points from the international discussion that were integrated in the Austrian 2023/24 curriculum for Geography and Economics are presented in what follows. In this context, the decisions of the Ministry of Education have played a considerable role: it is clear that the competence orientation of the education system is primarily a political decision, and not primarily an educational one.

The Austrian Ministry of Education's choice of a specific concept of competence from among the numerous definitions of the term was not explained (HofmannSchneller, 2011, p. 18). The ministry decided on Weinert's powerful definition of competence: "Competences describe the cognitive abilities available in individuals or learnable by them to solve certain problems, and the associated motivational, volitional and social willingness and ability to use the problems in variable situations successfully and responsibly" (Weinert, 2001, pp. 27-28). Very important for the Austrian discussion in the subject of Geography and Economics is the central concern that mere expert knowledge is insufficient; competence has to be thought of in terms of the interaction of expert knowledge, ability and will. This is similarly expressed in another widely used definition of competence: "Competences create the connection between knowledge and ability. They are to be seen as the ability to cope with different situations" (Klieme, 2004, p. 13).

An important application of these considerations for Geography and Economics was found in the specification for the competence-oriented school leaving examination, in which guidelines for the pool of topics and examination tasks were drawn up on behalf of the Ministry of Education (BMBF, 2012). In addition to the development of a competence model, competence-oriented tasks are highlighted as an important area. Instead of presenting fuzzy and thus misleading wh-question words (who, what, where, when, why etc.), the focus is on formulating competence- 
oriented tasks with useful materials, and developing the requisite skills to carry the tasks out.

The skills are characterized as follows (ibid., p. 13):

- Requirement area I - Reproduction: Repetition and simple reorganization of knowledge

- Requirement area II - Reorganization: complex reorganization of knowledge; easy application and transfer of knowledge to unknown areas

- Requirement area III - Reflection: complex application; complex transfer and real problem-solving.

After a meta-analysis of six studies, the US authors Anderson \& Kratwohl (2001) arrive at a similar structuring of the degree of difficulty, formulating cognitive process stages for learning tasks. In a manner similar to Bloom et al. (1956), they rank the following cognitive processes according to increasing complexity: remember, understand, apply, analyse, evaluate, create (Anderson \& Kratwohl, 2001, p. 28; see very similarly Reusser, 2014, pp. 329-330). Based on the operators used in both publications (Anderson \& Kratwohl, 2001; BMBF , 2012), the cognitive process dimensions 'remember' and 'understand' can be assigned to requirement area I, 'apply' and 'analyse' to requirement area II, and finally 'evaluate' and 'create' to requirement area III. At the same time, Anderson \& Krathwohl criticise the undifferentiated use of the term 'knowledge' and divide it into factual, conceptual, process and metacognitive knowledge at each cognitive process stage, thereby creating a two-dimensional matrix (Table 2). 
Table 2

Two-Dimensional Matrix Of The Cognitive Process Dimension And The Knowledge Dimension (Source: Anderson \& Krathwohl, 2001, Pp. 28-29 And 68; BMBF, 2012, Pp. 13-14; Designed By Christian Fridrich)

\begin{tabular}{|c|c|c|c|c|c|c|c|}
\hline & & & & \multicolumn{4}{|c|}{$\begin{array}{l}\text { The Knowledge Dimension } \\
\text { (of equal value and rank) }\end{array}$} \\
\hline & & $\begin{array}{l}\text { "Cognitive } \\
\text { Process } \\
\text { Dimension" } \\
\text { (Anderson \& } \\
\text { Krathwohl, } \\
\text { 2001, p. 28) }\end{array}$ & $\begin{array}{l}\text { "Requirement } \\
\text { Areas" with } \\
\text { Examples of } \\
\text { Operators } \\
(B M B F, 2012, \\
\text { p. } 13-14)\end{array}$ & $\begin{array}{l}\text { Factual } \\
\text { Knowledge: } \\
\text { terminology, } \\
\text { specific } \\
\text { details and } \\
\text { elements ... }\end{array}$ & $\begin{array}{l}\text { Conceptual } \\
\text { Knowledge: } \\
\text { classifications, } \\
\text { categories, } \\
\text { principles, } \\
\text { models ... }\end{array}$ & $\begin{array}{l}\text { Procedural } \\
\text { Knowledge: } \\
\text { subject- } \\
\text { specific } \\
\text { skills, } \\
\text { techniques, } \\
\text { methods ... } \\
\end{array}$ & $\begin{array}{l}\text { Metacognitive } \\
\text { Knowledge: } \\
\text { strategic } \\
\text { knowledge, } \\
\text { self- } \\
\text { knowledge ... }\end{array}$ \\
\hline \multirow{3}{*}{ 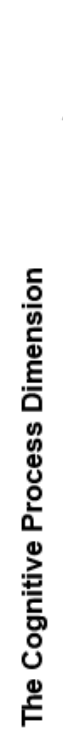 } & \multirow{3}{*}{ 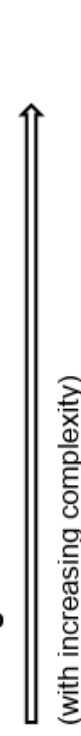 } & $\begin{array}{l}\text { Create: } \\
\text { generating, } \\
\text { producing } \\
\text { Evaluate: } \\
\text { checking, } \\
\text { critiquing } \\
\end{array}$ & \begin{tabular}{l}
$\quad$ III \\
\multicolumn{1}{c}{ Reflection: } \\
assess, review, \\
evaluate, \\
discuss, create \\
... \\
\end{tabular} & & & Example C & \\
\hline & & $\begin{array}{l}\text { Analyse: } \\
\text { differentiating, } \\
\text { attributing } \\
\text { Apply: } \\
\text { executing, } \\
\text { implementing }\end{array}$ & \begin{tabular}{l}
\multicolumn{1}{c}{$\quad$ II } \\
Reorganization: \\
analyse, \\
interpret, \\
explain, \\
compare, \\
create, justify ...
\end{tabular} & & Example B & & Example D \\
\hline & & $\begin{array}{l}\text { Understand: } \\
\text { explaining, } \\
\text { exemplifying } \\
\text { Remember: } \\
\text { recognizing, } \\
\text { recalling }\end{array}$ & \begin{tabular}{l}
\multicolumn{1}{c}{ I } \\
Reproduction: \\
name, \\
elaborate, \\
describe, \\
represent, \\
identify ...
\end{tabular} & Example A & & & \\
\hline
\end{tabular}

In the classroom, competencies can be addressed for each of the twelve fields that result from the combination of the three Dimensions of the Cognitive Process and the four Dimensions of Knowledge (Weinert, 2001, pp. 27-28; Klieme, 2004, p. 13) in the synthesis of knowledge, skills and willingness. This is explained using the four examples located in the matrix (Table 2). Example A refers to the reproduction of expertise, for example describing the unequal distribution of raw materials worldwide and identifying the locations of production networks for manufacturing mobile phones. Based on the analysis of conceptual knowledge, example B uses the key concept of 'interconnectedness and change' to analyse the extent to which human actions (e.g. those of mobile-phone purchasers) in one place can have an impact on people (e.g. mobile-phone production workers) in a faraway place, and the extent to which these networks change as a result of changing production and consumption conditions. The procedural knowledge addressed in Example $C$ is combined with requirement area III, for example when, with the help of the teaching method Mystery (Leat, 1998, pp. 51ff.), responsibilities, benefits and risks for participants in the thematic complex 'mobile phone production and use', including 
the dimensions of social, economic and ecological sustainability, are critically assessed from several perspectives. Example D can be used to address metacognitive competences, which are generally not sufficiently addressed in the German-speaking world - for example, the analysis of one's own learning path when structuring initially unstructured information, as when dealing with mysteries. In essence, this is about understanding and reflecting on one's own learning processes with the aim of being able to act in similar situations.

What are the characteristics of good competence-oriented learning tasks from a (subject-related) didactic point of view? In addition to curriculum conformity, clear task definition and provision of stimulating teaching material, student relevance, social relevance, multi-perspectivity, and avoidance of suggestive guidance are essential (BMBF, 2012, pp. 15-16). The last three criteria are also clearly expressed in the Beutelsbach Consensus on Political Education (Bundeszentrale für politische Bildung, 2011). From a general didactic perspective, Reusser adds that for learning tasks to be adequate, they should also include subject-specific core ideas for the promotion of competences (Reusser, 2014, p. 334). Such core ideas of a subject are called 'key concepts', which are discussed in the following section because of their importance for Geography and Economics.

\section{Key Concepts ${ }^{2}$}

Key concepts are understood, under the heading "from content to concept" (Fögele, 2016), as the basic architecture, basic structure, basic idea and basic principle of a teaching subject. In competence orientation, the focus is less on the accumulation of knowledge for the next test than on "moving away from the overfeeding of knowledge and the reproduction of teaching content" (Pichler, 2013, p. 19). Of course, a well-founded subject knowledge base (factual knowledge) is still required, but as one of four forms of knowledge, alongside conceptual knowledge, procedural knowledge and metacognitive knowledge (see Table 2). Conceptual knowledge includes knowledge of classifications and categories, knowledge of principles and generalizations and knowledge of theories, models, and structures (Anderson \& Krathwohl, 2001, p. 29). It also includes the key concepts of a subject.

For the specific situation of geography, the importance of key concepts can be summarized as follows: "Thinking geographically does, however, provide a language - a set of concepts and ideas - that can help us see the connections between places and scales that others frequently miss. That is why we should focus on geography's grammar as well as on its endless vocabulary. That is the power of thinking geographically" (Jackson, 2006, p. 203). Two British didacticians of geography also use the metaphor of grammar as an image of the architecture of a language when they refer to the fundamental importance of key concepts: "[A] list of key concepts certainly indicates the subject's architecture, or to revert to our earlier metaphor,

\footnotetext{
${ }^{2}$ I base my discussion here on Fridrich 2016.
} 
its 'grammar'. This in turn captures at least part of the subject's discipline" (Lambert \& Morgan, 2010, p. 40). In the context of 'powerful knowledge', which enables students to analyse, explain and evaluate the world beyond their personal experience, the application of concepts has a double meaning: both to think in new ways, and to make generalizations and apply them in new contexts (Maude, 2020).

Key concepts have valuable functions and properties. They provide guidance for learners, structuring the complex world from a professional perspective, breaking it down into manageable and coherent principles. Because learning usually builds on previous learning processes and existing knowledge, key concepts allow new knowledge to be integrated more easily with existing knowledge. Due to their mediating function between scientific concepts and the basic structures of the associated teaching subject, key concepts are also - in addition to being didactic decision-making aids - filters for relevance in the selection of subject content for school lessons. Key concepts have a further mediating function - between scientifically recognized concepts on the one hand and subjective theories or preconcepts that have sedimented out of individual previous experiences on the other. Key concepts thus promote the systematic further development of subjective concepts towards scientifically recognized theories through learning in similar thematic contexts. Key concepts are not to be understood in a monodisciplinary way: because of their high networking potential, they are relevant in integrated and combined subjects such as Geography and Economics, and to transdisciplinary teaching. Finally, the same topics and issues within key concepts can be dealt with in different and increasingly complex learning settings from several different perspectives, as appropriate to the particular school level (Fridrich, 2016, p. 25-26).

Discussion of key concepts came late to Austria, long after it had become important in Germany and England, for example. In England, key concepts were implemented as early as 1976, in the School Council Project for History, Geography and Social Science (Marsden, 1995). While one author names eight "Big Concepts" (cause and effect, systems, classification, location, planning, decision making, inequality, development) (Leat, 1998), other works unanimously cite the three key concepts place, space and scale (among others). For example, Holloway et al. (2003): place, space, scale, time, social formations, physical systems, landscape and environment; Jackson (2006): space and place, scale and connection, proximity and distance, relational thinking; finally, the UK 2008 Key Stage 3 Curriculum for Geography (QCA, 2007): place, space, scale, interdependence, physical and human processes, environmental interaction and sustainable development, cultural understanding and diversity. According to the Geographical Association, the three central key concepts are place, space and environment (Geographical Association, 2012 , pp. 3ff.), even though key concepts are not explicitly mentioned in the current National Curriculum for England, which was launched in 2014 (Department for Education, 2013; for further explanations, see Taylor, 2008).

In Germany, the document "Bildungsstandards im Fach Geographie für den Mittleren Schulabschluss" (German Society for Geography, 2014) established the 
term "key concept" in a broader sense. The human-environment system, which has subsystems for human geography and physical geography, is understood as a central key concept. It is subdivided into the components structure, function and process, at different levels of scale (ibid., p. 11). Based on the basic geographical concepts of the Geographical Association (see above), and detailed explanations and background information (Lambert, 2013, pp. 175ff.), the seven "geographical concepts", which are understood as an aid for structuring teaching (Uhlenwinkel, 2013a) for German school geography, are presented and discussed in a widely distributed handbook for the didactics of geography (Rolfes \& Uhlenwinkel, 2013). These seven concepts are: place (Uhlenwinkel, 2013b), space (Uhlenwinkel, 2013c), scale (Uhlenwinkel, 2013d), change (Wienecke, 2013), networking (Uhlenwinkel, 2013e), diversity (Kulick, 2013), and perception and representation (Wald, 2013).

In Austria, the ministerial working group for the Geography and Economics curriculum for upper secondary education (grades 9 to 12), comprising subject didacticians and teachers, introduced the key concepts and thus the subject didactic concepts around them. The curriculum 2016 group sees the key concepts formulated for Geography and Economics as a proposal, and offers an up-to-date summary of subject approaches. In addition, the group focuses on the reception of a broad international discourse, the framework of which should help students prepare for participation in social processes (Hof et al., 2016; Pichler \& Jekel, 2017, p. 6). Focusing on the current and expected lifeworlds of students and in terms of Geography and Economics, these preparations for participation in social processes include economics education (e.g. Fischer \& Zurstrassen, 2014), economic citizenship (e.g. Schank \& Lorch, 2015), spatial literacy (e.g. Bednarz \& Kemp, 2011), and spatial citizenship (e.g. Gryl \& Jekel, 2012). The common core of the diverse citizenship approaches lies in the increased integration into the curriculum of multiperspectival, reflexive and critical approaches. This is a further step away from the exclusive teaching of factual knowledge towards the development of students' competencies in engaging with the world, lifeworld analysis, and coping with everyday life (Pichler \& Jekel, 2017, p. 6).

The 13 key concepts embedded in the secondary school curriculum 2016 are spatial construction and spatial concepts; regionalization and zoning; diversity and disparity; scale; perception and representation; sustainability and quality of life; interests, conflicts and power; work, production and consumption; markets, and their regulation and deregulation; growth and crisis; human-environment relations; geo-ecosystems, and contingency (Bundesgesetzblatt für die Republik Österreich, 2016, pp. $60 \mathrm{ff}$.). Together with, on the one hand, the explanations about key concepts in general and the key concepts formulated in the Geography and Economics curriculum 2016, as outlined above, and, on the other hand, the requirements formulated below, they form the basis for the design of the key concepts for the curriculum 2023/24 for lower secondary level (grades 5 to 8). Key concepts should be quantitatively manageable, conceptually easy to understand, and relate to the basic didactic understanding of the subject. They should allow a 
smooth transition to the key concepts of upper secondary level (grades 9 to 12), give equal weight to Geography and Economics, the level of abstraction in their formulation should be as uniform as possible, and they should support the achievement of the objectives of the curriculum for lower secondary level.

Based on these considerations, the following seven key concepts were proposed for lower secondary level (grades 5 to 8) in a didactic publication (Fridrich, 2016) before the design of the curriculum 2023/24: interconnectedness, change, diversity, disparity, sustainability, power and scale. They form the basic structure around the core of the subject Geography and Economics, which is made up of people acting in the interplay of society-economy-politics-environment (see Figure 2).

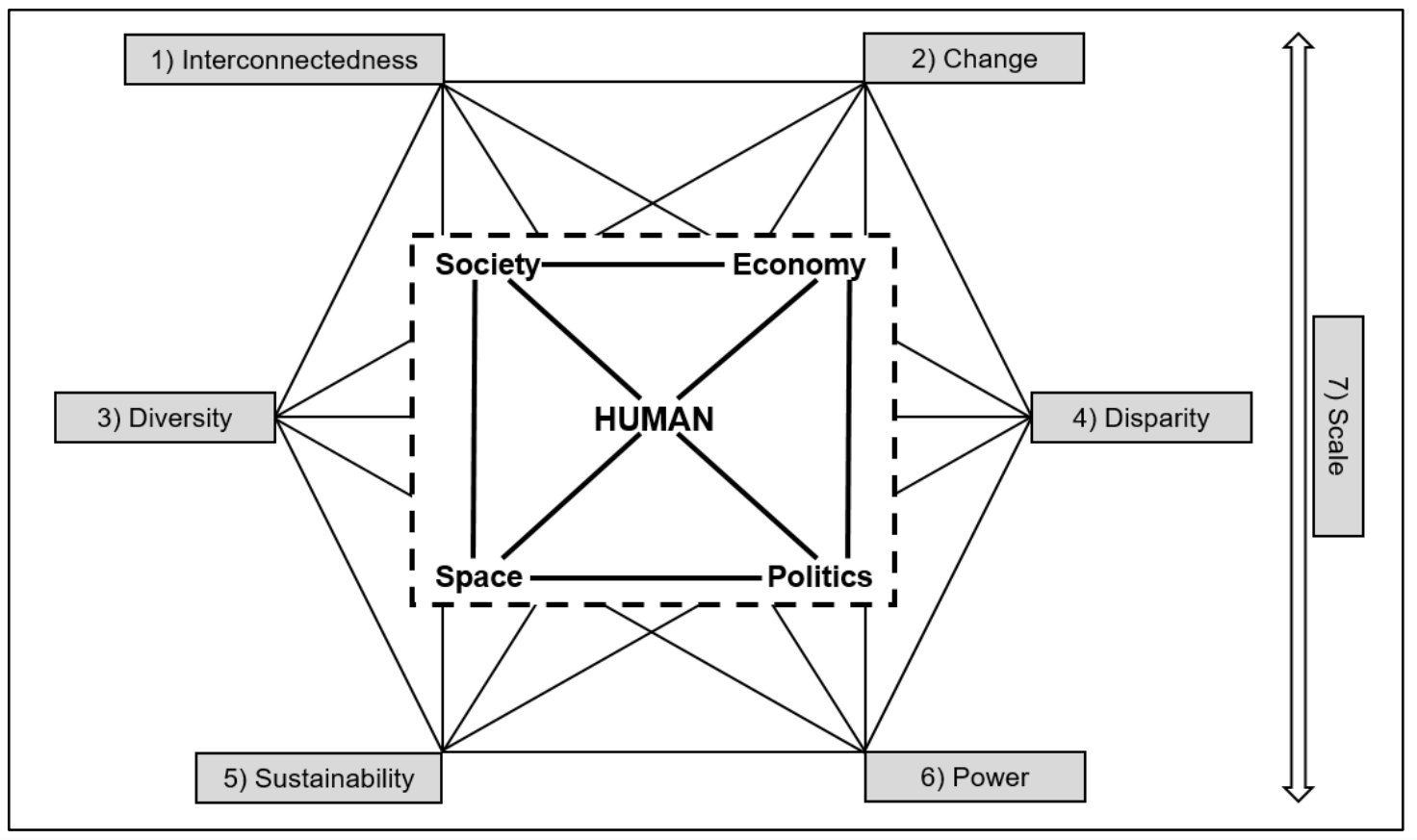

Figure 2. Core of Geography and Economics teaching, with the seven key concepts proposed for lower secondary level (graphic: Fridrich, 2016, p. 27)

\section{Economics Education}

The basic didactic understanding of the combined and integrated subject of Geography and Economics as already outlined is encapsulated in the opening statement of the 2000 curriculum for secondary education: "The human being is at the center of Geography and Economics. His/her activities and decisions in all areas of life always have spatial-structural foundations and effects. These spatial aspects of human activity are the subject of teaching. Particular attention will be paid to such interconnections using the example of the economy [...]" (BMB, 2000, p. 1).

The consequences of this for economics education were recorded in the position paper 'Socio-economic Education following an Austria-wide subject-related didactic discussion process' (Fridrich \& Hofmann-Schneller, 2017, pp. 56-57). They can be outlined as follows. If the focus of this subject is on people acting spatially and economically in social contexts, this includes young people and their living 
environments. The economy is therefore not seen as an independent system, but is embedded in society and even socially constituted (Hedtke, 2015, pp. 21-22). Therefore, the economy can be and is shaped by each individual according to his/her abilities, commitment and level of empowerment (Famulla, 2014, p. 404). Famulla makes it clear that individual citizens often have little power, but this can be increased considerably by cooperation in initiatives from the local to the supranational level. A central goal of economics education is to support the development of a considered appropriation of the world by young people, by promoting their ability to orientate, judge and act (Haarmann, 2014, pp. 208-209). The ability to orientate means finding one's way in a society that is highly economically penetrated, and its regulatory and institutional systems (see also Kutscha, 2014, p. 74). Societal ability to judge builds on this and means being able to position oneself competently and with self-determination, and thus to form a well-founded and ethically sound opinion (see also Ulrich, 2008, p. 14). Capacity to act includes the ability to participate in social, political and economic processes in the sense of self-determination and co-determination, in three (and sometimes more) interlinked areas: firstly in household contexts, with questions of how consumption and the private household are organized; secondly in work contexts, in paid and unpaid work, and with the integration of the employee's and employer's perspectives; and thirdly in social contexts, at local, regional, national and supranational level (Tafner, 2015, pp. 682ff.). Money and finance cuts across each of these contexts. Socio-economic education understood in this way is also about raising awareness of life-sustaining economic activity in all areas of life, and promoting young people's emancipation and participation, as well as their ability to accept criticism (Fridrich \& Hofmann-Schneller, 2017, p. 56).

This paradigm of socio-economic education is characterized by the following principles, to be implemented at classroom level (Hedtke, 2018, pp. 95ff., see also Famulla, 2019, p. 25):

- Learner-centerd approach: guaranteed by closely interweaving learners' previous experiences and their lifeworld orientation, which are at the center of the lessons. In addition, everyday challenges faced by students are taken up and worked on with the aim of increasing their ability to act. For example, topics could range from saving or spending their own available money, to civic, socio-economic participation.

- Problem orientation: no closely tailored, constructed problems are brought to the attention of the learners, but, rather, challenges and problems from the students' lifeworlds become educationally relevant. This is all the more important as there are a large number of (possibly conflicting) options for action.

- Social science: refers to the social embedding described above. Numerous concepts, such as consumption, interest, power, state etc., cannot be assigned to a single discipline such as Economics, but can only be developed in an inter- 
and transdisciplinary way in a cooperation between social and economic sciences.

- Pluralism: as a significant characteristic of modern societies, pluralism is closely linked to multi-perspectival content, which is why young people should also be confronted with different economic models, worldviews and interpretations of the world. It is therefore not a matter of presenting students with "value-free" economic activity, but of integrating many perspectives.

All these principles are, at least to some extent, in accordance with paradigm shift B of the two curricula of 1985/86 and 2000 and, thanks to their being clearly recognized in the discourse on socio-economic education, they are foundational in the new curriculum of 2023/24. Socio-economic education is therefore oriented neither towards Homo oeconomicus nor towards the "social physics" of the widespread neo-classical economy. Rather, "It is committed to the principles of interdisciplinarity, plurality and controversiality, as well as to permanent ethical reflection, in order to contribute to the paradigmatic opening of economics education" (Engartner, 2019, p. 94). As an interim summary, it is stated that the competence-oriented further development and formulation of socio-economics education is central to understanding Geography and Economics as a combined and integrated subject.

\section{Methodology}

\section{Research design ${ }^{3}$}

The overall study, which has so far only been published in excerpts, features an embedded triangulation design. This means that (a) in a large-scale quantitative study, there is (b) a qualitative element with open questions, which was integrated to achieve a deeper understanding. On the basis of the results, a second qualitative study (c) is conducted, whereby all results are subjected to "data triangulation" (Flick, 1995, p. 432) in order to identify both common positions and differences between the groups of respondents (Figure 3). While the participants in the first study of Geography and Economics in Vienna were teachers $(n=527)$ at lower secondary level (grades 5 to 8), in the second study they consisted of internal experts (subject didactics experts), and external experts (stakeholders from business-related interest groups, associations and other institutions). Here, we present only results from parts (a) and (b) of the study, which were carried out in 2011; the results were also used as an "internal" empirical basis for the further development and fine-tuning of the subject didactics - for example to inform the design of the $2023 / 24$ curriculum.

${ }^{3}$ For further details, see Fridrich, 2015, pp. 284-286 and Fridrich, 2020a, pp. 10-11. 
Fridrich, C. (2021). Skills in geography and economics reflected in austria's newly developed key...

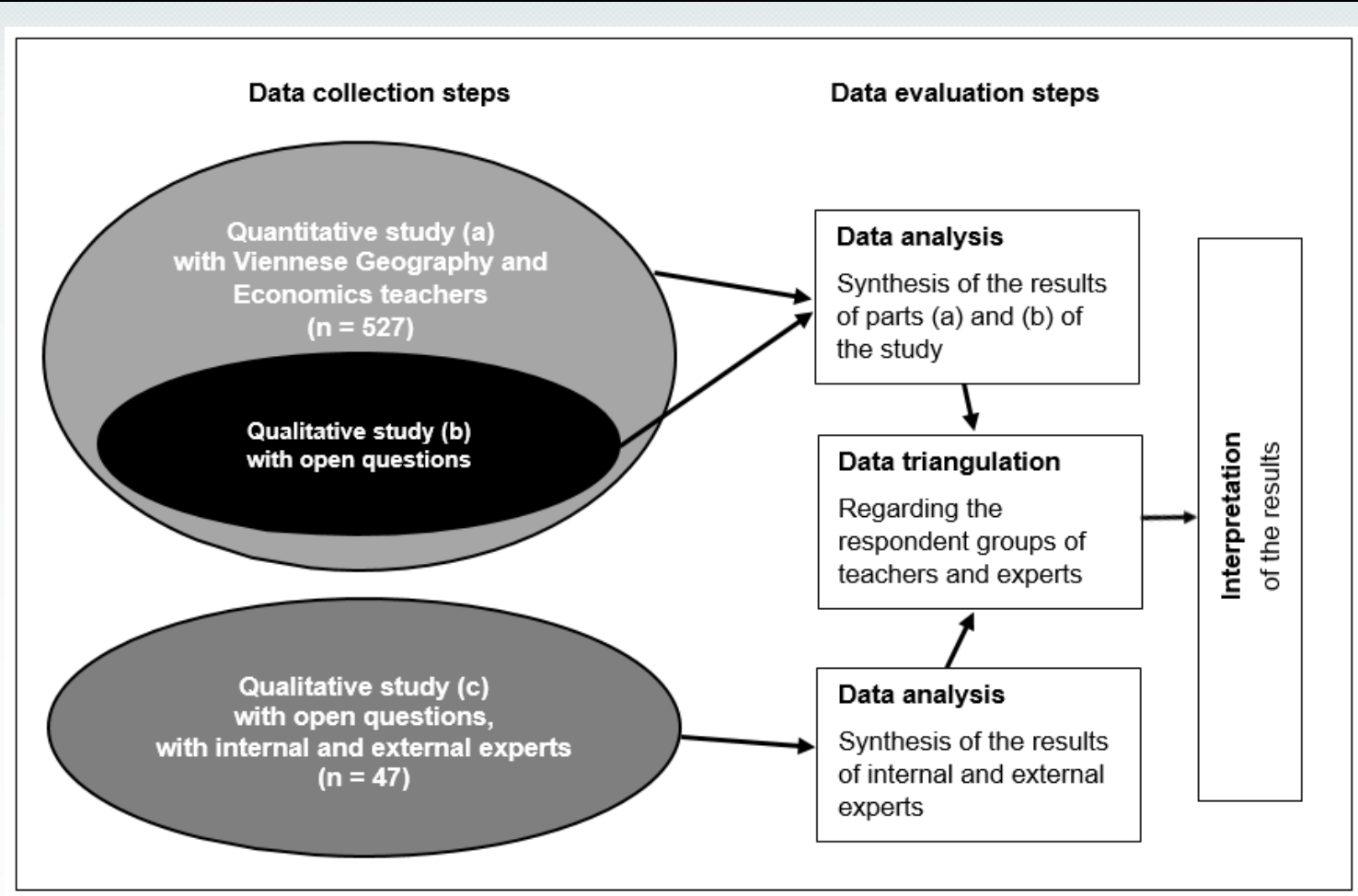

Figure 3. Research design with mixed methods and embedded triangulation (Source: own representation Christian Fridrich)

\section{Sample}

For the quantitative study with a qualitative component, the sample consists of Geography and Economics teachers at lower secondary level (grades 5 to 8), which comprises two types of school: the lower level of general secondary school ("Gymnasium"), and secondary school ("Hauptschule"). First, the head teachers were asked to approve the carrying out of written surveys at their schools. After approval, 802 questionnaires were handed over in person at the eligible schools, directly to the teachers who wished to participate. On the same day or shortly afterwards, the completed questionnaires were collected. The usable rate of the questionnaires that were returned was high $(65,7 \%)$ thanks to the personal handing out and collection of the questionnaires. 527 of the questionnaires were usable. Research assistants were on hand to answer technical and administrative questions personally, which also favoured a high level of support on the part of the teachers.

\section{Data Collection}

Data collection was via a pre-tested questionnaire, modified for the final version, with 21 items, 13 of which were closed questions. For this paper, three questionnaire questions are relevant for the over-arching research question ('How can the goal of the subject of Geography and Economics, which is to enable young people to act in the "society-economy-politics-environment" framework, be pursued and supported at curricular level?'): 
- Question (a): "Please complete the following sentence: The focus of Geography and Economics lessons is/are ...". [open question]

- Question (b): "How do you see the relationship between Geography and Economics? Please choose the answer that you think is most appropriate." The following four possible answers were offered: "Geography has nothing in common with economics, economics was 'grafted' onto geography many years ago." "In some areas or subjects, a combination of Geography and Economics is useful." "In many areas or subjects a combination of Geography and Economics makes sense." "For me, Economics is an integral part of Geography." [closed question]

- Question (c): "On average, what percentage of your teaching time specifically do you spend on geographical content, on economics content, and on the conscious linking of these?" [open question]

\section{Data Analysis}

The evaluation of the responses was carried out using the following analysis processes. For Question (c), first the arithmetic mean values of the individual percentages were calculated for all classes and across all classes, and then an analysis of variance was carried out (Field, 2009, pp. 462ff.). For Question (a), inductive category formation was implemented using qualitative content analysis according to Mayring (2000). After the main categories had been generated inductively, sub-categories were formed in a similar way. First, a uniform level of abstraction was determined for main and sub-categories in order to ensure comparability. Then the selection criteria were determined in order to identify only answers that fitted the topic. Next, about one tenth of the text corpus resulting from the stages just described was analysed to generate a preliminary category system. These preliminary categories were checked for usability and freedom from overlap, and subsequently refined. The main and sub-categories were then explained, and characteristic examples were provided in order to ensure that the text passages could be easily assigned to categories. The category system and the allocation of answers to categories were reviewed constantly during this phase. In the case of unclear text passages, a 'close context analysis' ensured that they were allocated correctly (Mayring, 2000, pp. 75ff.). The answers to question (a) also raised didactically hotly debated topics, such as the relative importance of traditional regional studies, topography and the position of the human being in Geography and Economics lessons. The responses were subjected to significance tests with regard to interviewees' number of years of service and level of education, in order to reveal deeper correlations between the two (Bortz, 1999).

If the answers to Question (b) are analysed in relation to two particular groups of respondents (termed E+ and E-; see The relationship between Geography and Economics from the teacher's perspective below for definitions), a significance test was also used. A supplementary significance test that used mixed methods was also carried out in the course of the qualitative evaluations of Question (b) (Kuckartz, 2014). 


\section{Findings}

\section{Central Concept of Geography and Economics Teaching From a Teacher's Perspective}

Research Question 1: What concept do teachers put at the heart of their Geography and Economics lessons?

In questionnaire Question (a), teachers were asked to complete the following sentence: "The focus of Geography and Economics lessons is/are ...". The curriculum for Geography and Economics at lower secondary level, which has been in force since 2000, gives a clear answer to this question. It is not the earth, not "space", not topography and not individual states that are the focus of Geography and Economics lessons, but rather the human being acting in all areas of life. Furthermore, it is not only the accumulation of isolated bits of knowledge that has to be handled, but also "the explanation of facts, contexts and developments of human action" (BMB, 2000, p. 1, emphasis added) - in other words, spatial-structural, economic, political and social contexts of human activity. Question (a) thus aims to determine the extent to which the paradigm shift has been received by teachers.

In pedagogical terms, putting the human being at the center of teaching means that students should be at the center of lesson planning, implementation and evaluation, and, moreover, should be perceived as whole persons. If they are to cope competently with life situations outside and after school, their interests in topics and content are just as important as the development and promotion of their skills. Thus the interrelation between students on the one hand and their lifeworlds on the other acquires a fundamental significance. Lifeworlds can be the starting point for teaching, and at the same time competences should be developed to help young people shape their lifeworlds responsibly and in a self-determined manner.

In addition, the educational missions of the curriculum include developing attitudes such as a sense of responsibility, tolerance, and democratic values, as well as skills such as orientation and working techniques. All of these should therefore play an important role in teaching Geography and Economics, even though they are not at the center of the curriculum.

By means of Mayring's (2000) qualitative content analysis, the following main categories were formed from respondents' answers to the question of what they considered to be at the center of their teaching. The categories were created using inductive category formation and by counting the number of mentions. They are ranked according to the frequency of assignment: Knowledge - Human - Contexts Skills and attitudes - Other. Figure 4 shows the percentage distribution of the main categories, which makes it clear that all other categories combined together dominate the category Knowledge in a ratio of 3 to 2 . 


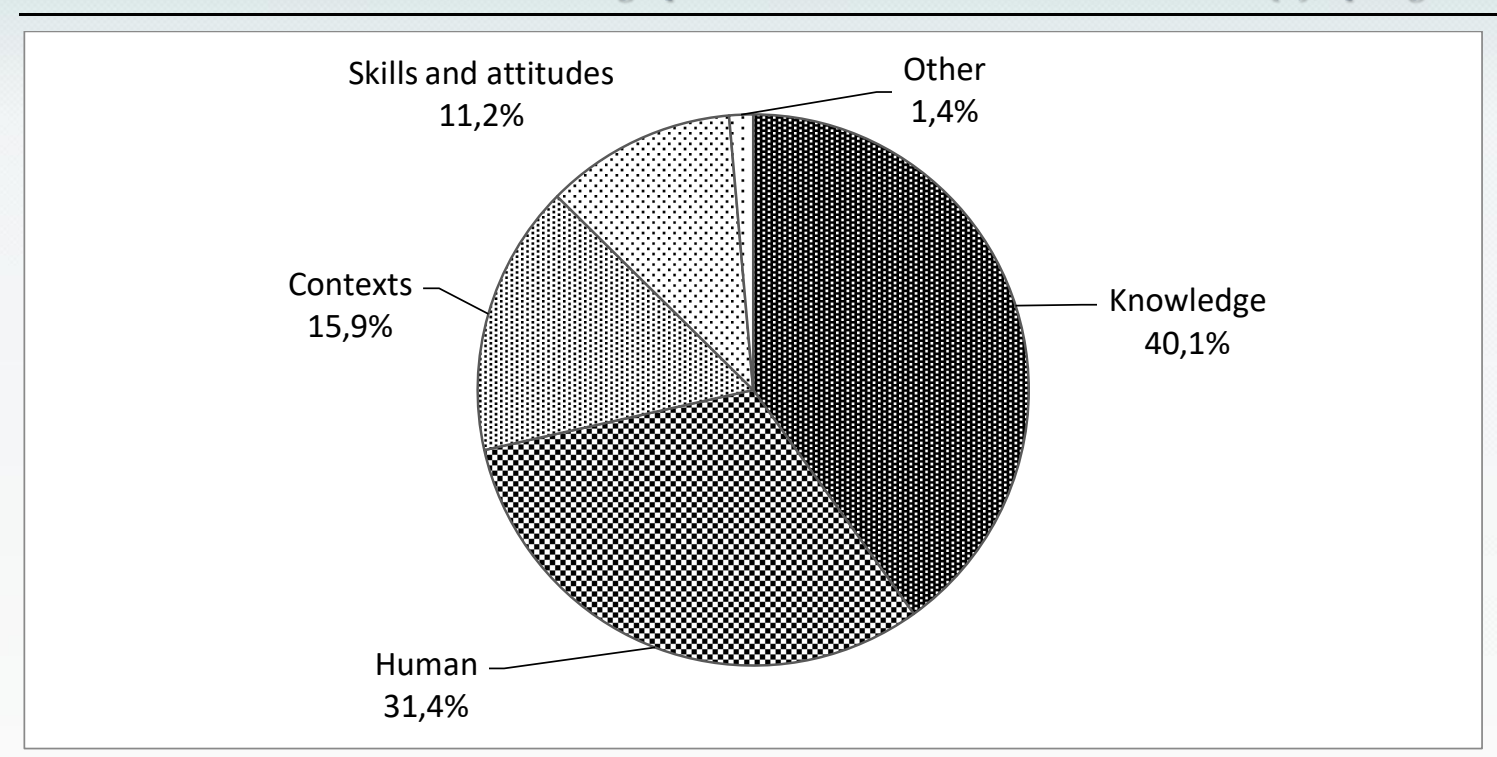

Figure 4. Percentages of answers assigned to each of the main categories identified by teachers as being at the center of their Geography and Economics teaching (Source: own presentation Christian Fridrich)

Now to the results of the individual main categories in detail.

(a) Main category "knowledge"

In about two-fifths of all answers, aspects of knowledge (general knowledge, geographical knowledge and economics knowledge) are at the center of Geography and Economics lessons. Quantitatively, aspects of geographical knowledge are mentioned about three times more frequently than knowledge of economics.

General knowledge is understood as the accumulated stock of knowledge that includes (a) general geographic and economics education, (b) overview knowledge of all Geography and Economics areas and the lifeworld generally, and (c) the basics of the subject. The teachers interviewed have repeatedly emphasized, then, that this is also practical, applicable knowledge.

Geographical knowledge in the broadest sense includes many traditional elements of "classical school geography". In first place are Austria - Europe - the world, with the world being mentioned most frequently and Europe least frequently; fairly often, this three-part sequence, which reflects the principle of 'from near to far', is mentioned explicitly. Given the more or less high proportions of children and young people with a migration background, it is unclear why Austria is considered the "home country", and not the countries from which they originate (but on the fundamental problem of the concept of homeland or home country, see e.g. Hasse, 1993). In addition to words and phrases that reflect a traditional view of the world, such 'continents', 'geography of the world', 'shape of the earth', 'large areas' or 'living spaces' and 'planet earth', many teachers also refer to the 'global village' or the 'multifaceted world' to characterize the comprehensive picture of the world at the center of teaching Geography and Economics. 
In second place - with almost a quarter of all mentions in the area of "geographical knowledge" - is country studies. In some cases, traditional country studies alone is cited as the focus of geography lessons, while in others it is mentioned as one of several areas, which often include topography. Answers that refer to topography rank third, immediately after regional studies, again sometimes as the sole focus of teaching Geography and Economics, sometimes as one area among others. The Geography and Economics curriculum calls for the "establishment of reference systems with the aid of subject-related equipment and techniques" (BMB, 2000, p. 1 ) in teaching and tasks to be carried out by students, without imposing them as the center of Geography and Economics education. In addition, the intention behind the Geography and Economics curriculum for lower secondary level was to teach topography not as an end in itself, but always in the context of specific topics and content, which is expressed in numerous responses. For topography, a significance test was carried out with regard to the three groups of Geography and Economics teachers: 'unexamined' Geography and Economics teachers at lower secondary schools (teachers who teach outside their own subject, without a formal qualification for teaching Geography and Economics), 'examined" Geography and Economics teachers at lower secondary schools, and Gymnasium teachers (all of whom are 'examined') at lower secondary level (grades 5 to 8). This test also showed a statistically significant correlation between naming topography and the three groups of Geography and Economics teachers $\left(\chi^{2}(1, \mathrm{~N}=499)=6.527 ; \mathrm{p}=0.038\right)$. While $9.6 \%$ of the examined Geography and Economics teachers and $6.8 \%$ of the unexamined ones give topography as being at the center of their Geography and Economics teaching, only $3.0 \%$ of the Gymnasium teachers do so. When traditional regional studies is named, there is no statistically significant correlation between this and the number of years of service. In fourth place are areas related to geography, such as (from most to least frequently mentioned): human geography, physical geography, regional geography, ecology, climate, geomorphology, population geography, soil, contemporary history.

Economics knowledge is cited significantly less often than geographical knowledge as the center of Geography and Economics teaching, with the ratio of mentions of geography and of economics being around 3 to 1 . The importance of economics topics in general is emphasized with more or less equal frequency, while individual areas or topics of economics are cited as follows. Dominating, in first place, is the importance of preparation for and insight into the world of work and vocational orientation. This is followed by topics relating to globalization, the world economy and national economy, before topics relating to private households and sustainable management.

b) Main category "People"

Just under a third of the answers to this question refer to the curriculum intention that people should be at the center of Geography and Economics teaching. The answers also reflect the twofold viewpoint as formulated at the beginning of this 
section: on the one hand, the human being as a formative actor in his/her lifeworld, and on the other hand the pedagogical viewpoint of the human being as the center of instruction, the latter being mentioned somewhat more frequently than the former. It is revealing to examine the connection between the main category "people" or "human beings" and the same three groups of Geography and Economics teachers (i.e. unexamined Geography and Economics teachers at lower secondary schools, examined Geography and Economics teachers at lower secondary schools, and Gymnasium teachers). The test shows a statistically significant correlation between naming humans as the center of Geography and Economics teaching and the three groups of teachers $\left(\chi^{2}(2, N=499)=16.485 ; p<0.001\right)$. Only $28.6 \%$ of the unexamined teachers cited the human being as the center of Geography and Economics teaching. Of the examined teachers, $42.6 \%$ saw the human being as the center of their teaching, compared to $49.5 \%$ of the teachers at Gymnasium. Examined teachers thus adequately take account of the acting human being much more frequently than do the unexamined Geography and Economics teachers.

The independence of the two characteristics "naming the human being as the center of Geography and Economics teaching" and "years of service of Geography and Economics teachers" was then checked by means of $\chi^{2}$ independence tests. The null hypothesis that the two characteristics are independent is rejected: $\chi^{2}(1$, $\mathrm{N}=479)=11.46 ; \mathrm{p}=0.001$. Around half (48.7 \%) of the Geography and Economics teachers with up to 20 years' experience place the person at the center of teaching Geography and Economics, while only around a third (33.5\%) of those with more than 20 years' service do so. This difference is probably due to the current training of Geography and Economics teachers.

In what follows, the subcategories of the main category "People" generated in the qualitative content analysis are presented.

The human being as the center of teaching: in this context, it should first be emphasized that the interest of the students is at the heart of teaching Geography and Economics. It seems important to teachers to arouse their students' interest in something: their own future, daily political events, economics and politics, Geography and Economics more generally, or the joy of learning. Placing the human being at the center of teaching also includes taking the students seriously as human beings, through discussions, by taking their needs into account, and helping them to develop into responsible citizens beyond the classroom.

This aspect, i.e. taking into account learners' lives outside and after school, was repeatedly stated by the teachers as being at the center of teaching Geography and Economics. More precisely, this means that the knowledge, skills and abilities acquired and developed in the classroom must be applicable in the everyday lives and lifeworld of the students as responsible citizens. The importance of applicability is seen in the following formulations: 'implementation of the contents in practical life', 'creating transfer into everyday life' and 'the ability to apply learned contents in a connected way'. 
Let us now turn to the second possible view of the human being at the center of teaching Geography and Economics, namely the human being as a formative actor in the environment in which he/she lives. This is where human life and economic activity are most frequently mentioned according to the mission of the curriculum. On the one hand, the acting human being is perceived as a social individual, which certainly includes his/her ability to shape the world and recognize the possibilities of acting in networks. On the other hand, human action is often cited as having a negative impact on society and the environment. Thus people act in an ambivalent manner, both as maintainers/designers and as exploiters/destroyers. These actors are in the foreground, while the semantic differences between 'earth', 'space', 'nature' and 'the environment' are hardly evident in the answers, because the terms appear to be used synonymously. The need for reflection and reflexivity on the part of the students is mentioned again and again.

This is matched by answers which refer emphatically to the importance of the lives and economies of other humans, other cultures, religions, lifeworlds, ways of life, living conditions, living spaces and different continents. Sometimes this is expressed in a differentiated way, sometimes in a superficial way. The teachers interviewed said that it is important to introduce students to the diversity of human beings and societies, promote tolerance towards the other both 'there' and 'here', and foster understanding of the 'foreign'.

(c) Main category "inter-relationships"

"Connections" or "inter-relationships" also play an important role in the eyes of the Geography and Economics teachers surveyed. About one sixth of the answers refer to different contexts, focus on the type of context (social, political ...), the importance of such contexts for learners, and finally give examples of contexts.

Many teachers consider it important to make the connections within and between individual areas understandable to their students, such as the interrelatedness implied in human-space-economy or society-environment. Again and again, relationships involving politics are cited; social issues are also mentioned, as are the world of work, socio-economic structural change, resources, climate and topography. It is noticeable that in these usually shorter answers, terms are used synonymously when referring to networks, for example human/society/population, geography/space/habitat/spatial structures, or the environment/ecology.

Repeatedly, the importance of and need to understand relationships is emphasized. Understanding inter-relationships and networks is seen as being just as important as promoting networked thinking through networked observations. Examples of networked observations and thinking are discussions of current events, global connections, regional developments, economic relationships and crosslinked thinking. Ultimately, such thinking leads to a deeper treatment of topics or problems in the classroom, such as 'Why are the realities of our world as they are?' and 'What are these realities connected to?'. 
d) Main category "skills and attitudes"

In no other main category does a subcategory dominate as much as in this one. The topic of orientation or map work comes up in more than half of the mentions of skills. There is no doubt that orientation is an important skill that needs to be developed and promoted in the Geography and Economics classroom. Orientation competence is seen as very important for students, who have to find their way literally in their living space, in Austria, and also figuratively, in the world. For the former, the focus is on map work and topographical skills (e.g. creating a rough topographical grid, secure classification of topographical terms, development of an adequate mental map) and working with other cartographic representations, diagrams and tables. The atlas and atlas work are mentioned most frequently in this context. Some teachers, however, place maps and atlases at the center of their teaching, which does not respond to the express intention of the curriculum.

Independent action in the classroom comes in second place among the "skills" mentioned. Students are to be enabled to work independently, and to work on topics in a practical and open manner, in collaboration with each other, although in a somewhat narrower view this may also mean working independently on content from a book. The independent acquisition of information is also mentioned here.

Attitudes in relation to actions in economic and political areas are also considered significant, for example in the sustainable use of resources or in one's own political actions (e.g. participation in rallies or demonstrations), but also in general terms in linking economies with ethical attitudes, or in critically addressing economic issues. Ultimately, in the view of some teachers, this requires the promotion of empathy and tolerance, and the development of the students' own values in a globalized world.

e) Main category "Other"

Only about one percent of the answers remain so general or unclassifiable that they have to be assigned to the category "other". These responses include "from the known into the unknown", the importance of education as well as equal rights, subject-specific instruction using a particular methodology or didactic approach and, finally, many different topics and different aspects are mentioned.

\section{The Relationship between Geography and Economics from the Teacher's Perspective}

Research Question 2: To what extent do teachers of Geography and Economics perceive Geography and Economics as combined subjects, or as being integrated, or as having no relationship to each other?

Hypothesis: Geography and Economics teachers with a positive attitude to the economy (E+) believe more often than teachers with a negative attitude to the economy (E-) that Economics is an integral part of Geography, or that the combination of Geography and Economics makes sense in many areas. 
Fridrich, C. (2021). Skills in geography and economics reflected in austria's newly developed key...

Questionnaire Question (b): "How do you see the relationship between Geography and Economics? Please choose the answer that you think is most appropriate." Four possible answers were offered: "Geography has nothing in common with Economics; Economics was 'grafted' onto Geography many years ago." "In some areas or subjects, a combination of Geography and Economics is useful." "In many areas or subjects, a combination of Geography and Economics makes sense." "For me, Economics is an integral part of Geography."

Almost two and a half times as many E- teachers as E+ teachers think that in some areas or topics a combination of Geography and Economics makes sense. Conversely, more than twice as many E+ teachers as E- ones say that, for them, Economics is an integral part of Geography. The correlation between E- teachers and attitude towards the relationship between Geography and Economics is statistically significant $\left(\chi^{2}(\mathrm{df}=3)=44.4\right.$; Cramérs $\left.\mathrm{V}=0.31 ; \mathrm{p}<0.01\right)$.

It is noteworthy in the overall result that Geography and Economics is perceived by $44.2 \%$ of the teachers surveyed as an integrated subject, and by $55.0 \%$ as a more or less combined subject. Less than $1 \%(0.9 \%)$ do not recognize any connection between the two subject elements (Table 3 ).

Table 3

Teachers' Perception Of Geography And Economics As Being Integrated, Or Combined, Or As Having Nothing In Common With Each Other (Source: Own Account)

\begin{tabular}{|c|c|c|c|}
\hline & $\mathrm{E}+$ & E- & Total \\
\hline $\begin{array}{l}\text { Geography has nothing in common with Economics; } \\
\text { Economics was 'grafted' onto Geography many years } \\
\text { ago. }\end{array}$ & $0,8 \%$ & $1,0 \%$ & $0,9 \%$ \\
\hline $\begin{array}{l}\text { In some areas or subjects, a combination of Geography } \\
\text { and Economics is useful. }\end{array}$ & $13,7 \%$ & $33,7 \%$ & $22,8 \%$ \\
\hline $\begin{array}{l}\text { In many areas or subjects, a combination of Geography } \\
\text { and Economics makes sense. }\end{array}$ & $28,1 \%$ & $37,0 \%$ & $32,2 \%$ \\
\hline For me, Economics is an integral part of Geography. & $57,4 \%$ & $28,4 \%$ & $44,2 \%$ \\
\hline Total & $100 \%$ & $100 \%$ & $100 \%$ \\
\hline $\begin{array}{l}\text { Note: } \\
\text { E+ Geography and Economics teachers with positive } \\
\text { attitude to the economy } \\
\text { E- Geography and Economics teachers with negative } \\
\text { attitude to the economy }\end{array}$ & & & \\
\hline
\end{tabular}

\section{The Interactively Implemented Geography and Economics Teaching From the Teacher's Perspective}

Research Question 3: To what extent is Geography and Economics taught in an integrated manner?

Hypothesis: According to the 2000 Geography and Economics curriculum, the proportion of topics dominated by economics is significantly higher in the third grade than in the first and second grades - but this higher proportion in the 
curriculum is unrelated to a larger proportion of economics content in Geography and Economics lessons.

Questionnaire Question (c): “On average, what percentage of your teaching time specifically do you spend on geographical content, on economics content, and on the conscious linking of these?"

Table 4 clearly shows that the shares of (a) economics content and (b) the conscious integration of geography and economics content both increase continuously from grade 5 to grade 8 . An analysis of variance between the shares of teaching time for the three areas of geography content, economics content and conscious integration (and this for grades 5 to 8) showed that the shares of all three differ significantly between the school levels. For geography content: $F(2.55$; 1004.87) = 316.16; $\mathrm{p}<0.01$; for economics content: $F(2.77 ; 1090.23)=180.51 ; \mathrm{p}<$ 0.01 ; for conscious integration: $F(2.32 ; 914.90)=91.31 ; p<0.01$. For this reason, the hypothesis is rejected. The higher proportion of economics content in the curriculum has a significant effect: it leads to more teaching time for economics topics (see further Fridrich, 2020b, pp. 30-31).

Table 4

Relative Shares in Teaching Time of Geography Content, Economics Content, and Their Integration for Geography and Economics at Lower Secondary Level (Grades 5 To 8) In 2011 (Source: Modified From Fridrich, 2020b, P. 30)

\begin{tabular}{|l|l|l|l|l|l|}
\hline & Grade 5 & Grade 6 & Grade 7 & Grade 8 & $\begin{array}{l}\text { Arithmetic } \\
\text { mean }\end{array}$ \\
\hline $\begin{array}{l}\text { Conscious } \\
\text { integration of } \\
\text { Geography and } \\
\text { Economics } \\
\text { content }\end{array}$ & $17,7 \%$ & $19,9 \%$ & $22,9 \%$ & $25,0 \%$ & $21,3 \%$ \\
\hline $\begin{array}{l}\text { Economics } \\
\text { content }\end{array}$ & $21,6 \%$ & $31,7 \%$ & $33,0 \%$ & $35,4 \%$ & $30,2 \%$ \\
\hline $\begin{array}{l}\text { Geography } \\
\text { content }\end{array}$ & $60,7 \%$ & $48,5 \%$ & $44,1 \%$ & $39,6 \%$ & $48,5 \%$ \\
\hline
\end{tabular}

The arithmetic mean for each of the three areas is visualized in Figure 5, the largest percentage share being for geographical content for the year 2011. There was a need to catch up in the integration of geography and economics content in teaching. 
Fridrich, C. (2021). Skills in geography and economics reflected in austria's newly developed key...

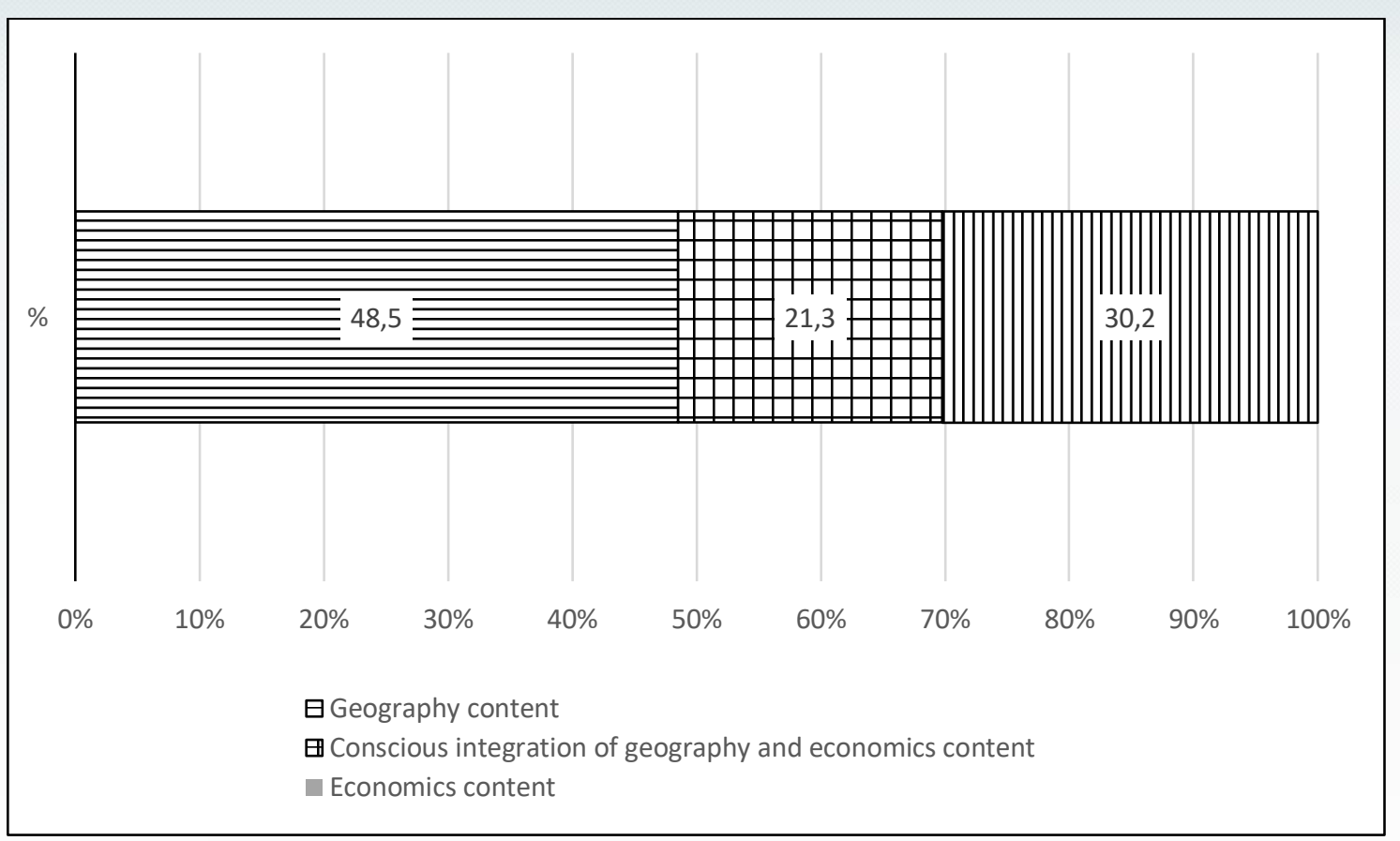

Figure 5. Relative shares of geography content, economics content, and their integration in teaching time for Geography and Economics in all classes (arithmetic mean) in 2011 (Source: modified from Fridrich, 2020b, p. 30)

\section{Result and Discussion}

\section{Discussion of the Findings With Regard To the 2023/24 Curriculum}

The empirical data show the following aspects of curriculum development. For most teachers, the students' acquisition of knowledge in general, and in geography and economics contexts specifically, is central to Geography and Economics. This is followed by the central position of the human being in the classroom, namely in terms of student orientation and the human being as an actor in shaping his/her own lifeworld. Contexts are perceived as essential, especially spatial-societyeconomics contexts and human-environmental systems, both of which include some elements of a political framework. In the interviewees' assessments, the importance of regional studies and topography as ends in themselves are cited significantly less frequently as the teacher's level of training increases, which corresponds to the intention of the 2000 curriculum. Teachers with fewer years of service mention the centrality of the human being in Geography and Economics lessons significantly more often, which indicates conforming to the curriculum on the one hand, and the results of a greater focus on this centrality in teacher training on the other. In addition, skills (above all orientation, map work and independent action), and attitudes in ethical and moral contexts are perceived as being of central importance for students. For the new 2023/24 curriculum, this means that the strategy of placing the acting person at the center of teaching must continue, and the contexts for action must be made even more explicit. 
Teachers' perceptions of the relationship between Geography and Economics depends, among other things, on their attitude to the economy (referred to above as E+ or E-). Thus integrated perceptions of Geography and Economics increase significantly among E+ teachers. Overall, Geography and Economics is perceived by more than half as an integrated subject and by less than half as a combined subject. For the new 2023/24 curriculum, this results in the demand for increased integration of Geography and Economics in the formulation of competence-oriented learning objectives.

However, the implementation of the integrative relationship lagged behind the positive perceptions described above in the survey year 2011: the integration of Geography and Economics increases significantly with increasing school level ( $^{\text {th }}$ to $8^{\text {th }}$ grades), but from a subject-related didactic perspective it can be assessed as being, on average, still too low. For the new curriculum, in addition to the formulation of integrative competence-oriented learning objectives, this results in the formulation of integrative key concepts and a competence model. These concepts and the model were among the requirements that the Ministry of Education put to the curriculum working groups of all subjects. In addition, on the basis of these empirical findings, the general need to create, test and publish freely accessible exemplary teaching materials to support teachers became apparent.

All in all, the empirical results suggest that the approach taken in the 1985/86 and 2000 curricula should not only be continued, but also further deepened in an integrative manner, strengthening the relationships between geography and economics perspectives and implementations in the classroom.

The details for key concepts and competences in the 2023/24 curriculum presented below are based on the theoretical concepts discussed in this paper namely competence orientation, key concepts and economics education - and on these empirical findings ${ }^{4}$.

\section{Implementation 1: Key Concepts In The 2023/24 Curriculum}

In accordance with the Austrian Ministry of Education's directive, each subject had to formulate key concepts for upper secondary level (grades 9 to 12), building firstly on the theoretical considerations outlined above, and secondly on the possibility of interlocking with the key concepts of upper secondary level (grades 9 to 12). A total of five so-called "central subject-related concepts" for Geography and Economics were identified and formulated, which are to be implemented in the classroom with the help of adequate case studies. These key concepts will be

${ }^{4} \mathrm{All}$ the aspects and topics just mentioned - including the key concepts, competences and socio-economic education described here - were introduced by members of the curriculum group in a collaborative way. The author of this paper is also a member of the curriculum group. The core group consists of, in alphabetical order, Carina Chreiska-Höbinger, Christian Fridrich, Stefan Hinsch, Paul Hofmann, Herbert Pichler and Marcel Vorage; an additional group comprised Thomas Jekel, Lars Keller and Alfons Koller. All were members of the curriculum group Geography and Economics as a whole (abbreviated: Curriculum Group GW). 
developed and formulated in the "society-economy-politics-environment" framework:

Similarities and differences: in the lives and economies of people, also in the context of diversity and disparity; recognizing differences in individual perception and representation. Interconnectedness and change: in society, humanenvironment relations and the economy; explanation of economic contexts that demonstrate interconnectedness, for example market relationships, or economic activities outside the market.

Interests and power: of people, groups and institutions; common, different and conflicting interests, and the resulting social inclusion and exclusion processes; making political decision-making processes transparent.

Values and identities: and their formation, using examples from numerous areas of life; own identity and affiliation; multiple identities and affiliations of people. Levels of scale and space: analyses and representations of social, economic and physical structures and processes; inclusion of different levels of scale, from the local to the regional to the global; different spatial concepts such as "container space", individual perception of places, and socially-constructed space; resulting multi-perceptivity in analyses (see Curriculum Group GW, 2020, p. 3).

\section{Implementation 2: Competences in the 2023/24 Curriculum}

In view of the global challenges of the $21^{\text {st }}$ century, which have been extensively documented in specialist literature, such as climate change, loss of species, resource consumption, flight and migration, democratic deficits, socio-economic disparities, economization of all areas of life, digital and global economic change and the green economy, it was necessary to integrate these topics appropriately. The particular challenge of formulating competences in the new curriculum consisted in following the specific requirement of the Ministry of Education that no more than ten competences were to be formulated per grade, and each grade had to be described using a maximum of ten sentences to express its competence-oriented learning objectives. In conjunction with the theoretical considerations on competences and the available empirical findings, this required a sophisticated formulation of competences that had at the same time to be readily comprehensible.

As an example, the advanced draft for the ten competences of the $8^{\text {th }}$ grade is given here. Each class in Geography has a general theme (here: globally interconnected life and economic activities), and superordinate areas of competence for which specific related competences are detailed (see Table 5). 
Table 5

Exemplary Illustration: Advanced Draft of The Curriculum For The $8^{\text {th }}$ Grade In Geography And Economics, Structured According To Competences And Areas of Competence (Source: Curriculum Group GW, 2020, P. 8)

\begin{tabular}{|c|c|}
\hline \multicolumn{2}{|c|}{$8^{\text {th }}$ grade: Globally interconnected life and economic activities } \\
\hline $\begin{array}{l}\text { Area of } \\
\text { competence and } \\
\text { application } 1 \text { : } \\
\text { Humans and } \\
\text { natural systems }\end{array}$ & $\begin{array}{l}\text { The students will be able to ... } \\
4.1 \text { describe the extent of human influence on natural systems using examples such as the } \\
\text { impact of pollutants, land and resource use (including own observations). } \\
4.2 \text { analyse the consequences for life and economic activity of exceeding the Earth's pollution } \\
\text { limits, climate change or species extinction. } \\
4.3 \text { reflect on the changing relationship between humans and nature and develop their own } \\
\text { ideas for sustainable action. }\end{array}$ \\
\hline $\begin{array}{l}\text { Area of } \\
\text { competence and } \\
\text { application 2: } \\
\text { Europe and } \\
\text { European } \\
\text { Integration }\end{array}$ & $\begin{array}{l}\text { The students will be able to ... } \\
4.4 \text { describe different structures, perceptions and representations of Europe and the } \\
\text { European Union in all its diversity, analyse them in (geo)media, and take a critical stance. } \\
4.5 \text { justify the importance of common values such as peacekeeping, democracy or freedom, } \\
\text { and reflect on central themes of the EU such as the Four Freedoms, the euro, educational } \\
\text { cooperation, quality standards, consumer protection, or regional development in relation to } \\
\text { their own lives. } \\
4.6 \text { discuss opportunities and challenges of European integration and the need for and } \\
\text { difficulty of common solutions to problems at European level in a globalized world. }\end{array}$ \\
\hline $\begin{array}{l}\text { Area of } \\
\text { competence and } \\
\text { application 3: } \\
\text { Developments in } \\
\text { a globalized } \\
\text { world }\end{array}$ & $\begin{array}{l}\text { The students will be able to ... } \\
4.7 \text { describe and compare the development, significance and distribution of cities, } \\
\text { conurbations and peripheries using (geo)media. } \\
4.8 \text { investigate and present possibilities and limits of cooperation as well as changes in power } \\
\text { relations between states, alliances, NGOs, corporations, international organizations and } \\
\text { movements. } \\
4.9 \text { identify winners and losers of the changing global economic networks and explain the } \\
\text { consequences of unequal development, for example for poverty and prosperity, conflicts of } \\
\text { use, ecosystems, migration and flight. }\end{array}$ \\
\hline $\begin{array}{l}\text { Area of } \\
\text { competence and } \\
\text { application } 4 \text { : } \\
\text { My life in an } \\
\text { interconnected } \\
\text { world }\end{array}$ & $\begin{array}{l}\text { The students will be able to ... } \\
4.10 \text { identify, compare and reflect on their own ideas about the future, wishes and needs in } \\
\text { terms of individual development opportunities, financial framework conditions, quality of life } \\
\text { and common challenges, and help shape political processes. }\end{array}$ \\
\hline
\end{tabular}

The formulation of the competences was carried out according to the competence model; it reflects, in addition to the three didactic concepts 'competence orientation', 'key concepts' and 'economics education' already discussed, the systematic integration of household, consumer, labour and social economics. Furthermore, the curriculum for Geography and Economics contributes to economic, political, informatics, linguistic and ecological education, as well as to the topic 'entrepreneurship education'.

The paradigm shift since the 2000 curriculum is also evident in the consolidation of the integration of Geography and Economics with each other. If we look, for example, at the ten competences in the $8^{\text {th }}$ grade, we see clearly that only competence 4.4 (if we interpret it strictly) has predominantly geographical references; all other competences are formulated in an integrative way. However, with this competence, integrative implementations are of course possible in teaching, if, for example, the different divisions, perceptions and representations of Europe and the European Union are made in such a way as to focus on society and 
Fridrich, C. (2021). Skills in geography and economics reflected in austria's newly developed key...

the economy. Seen in this light, all the objectives of the $8^{\text {th }}$ grade (and also of the other three grades) are formulated in an integrative manner, or could be implemented in an integrative way in the classroom. This reflects the intention of the Geography and Economics curriculum group.

A rather 'strict interpretation' of the total of 37 competences of the new curriculum according to predominantly geographical, predominantly economic, or integrative geographical-economics competences yields the following - concluding - picture (Figure 6). Three quarters of the competences can be clearly assigned to integrative formulations and intentions, thus expressing the basic orientation of Geography and Economics as an integrated subject.

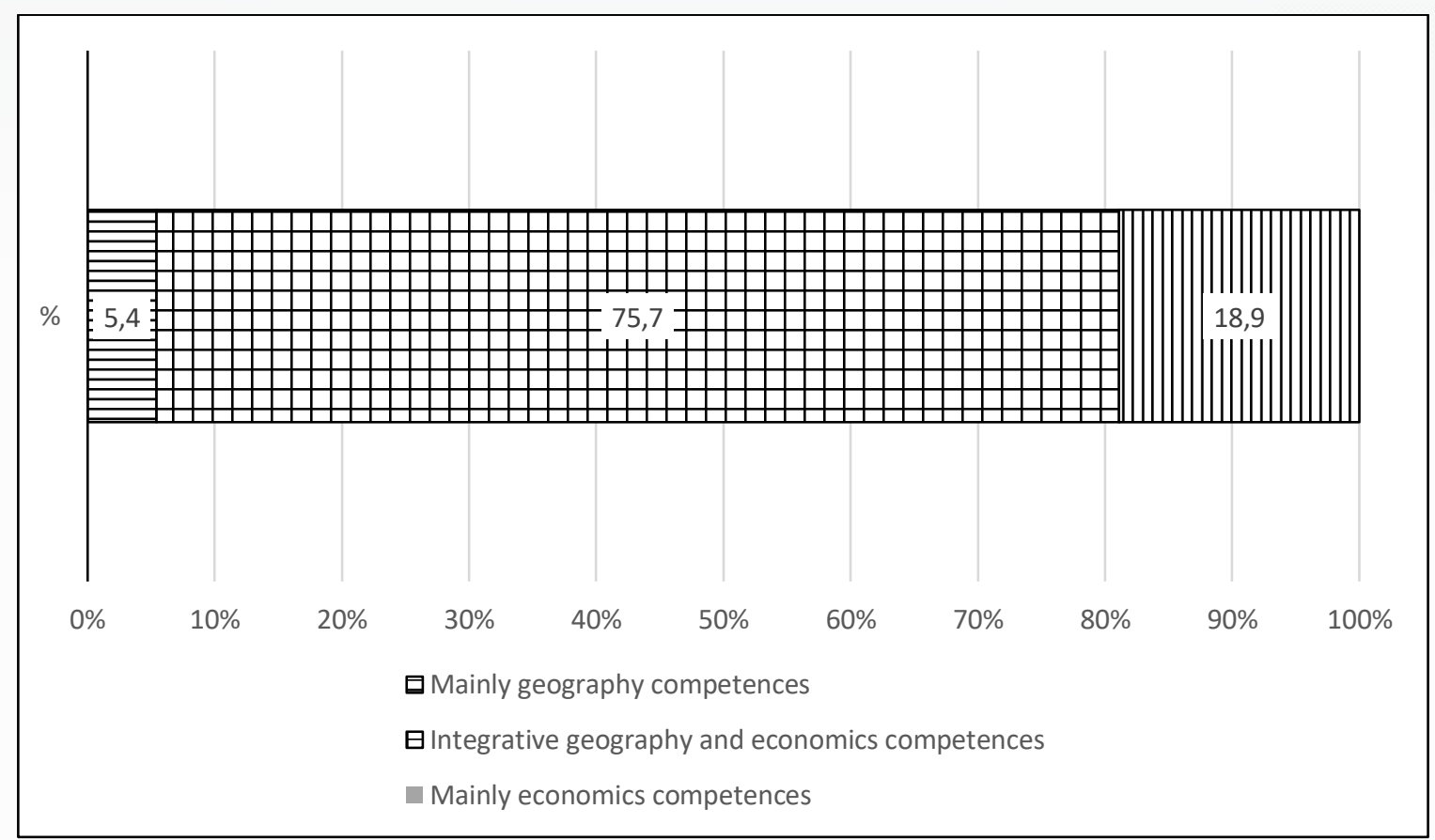

Figure 6. Percentages of the mainly geography, the mainly economics, and the integrative geography and economics competences of the 2023/24 curriculum for lower secondary level (grades 5 to 8) in Geography and Economics (Source: own calculation and presentation Christian Fridrich)

\section{Acknowledgement}

The empirical part of this research project was carried out with the support of the University of Teacher Education Vienna, for which the author would like to express his gratitude. My special thanks go also to Gerhard Paulinger (University Vienna) for his support in statistical calculations in Section "Findings". As part of their internships at the Institute for Educational Sciences at the University Vienna, a number of students worked on this research project, mainly in supporting its datacollection and data-entry phases. I would like to take this opportunity to thank them once again for their dedicated work: Maria Amon, Julia Englert, Brigitte Haberl, Isabella Holzmann, Felicitas Koularas and Astrid Stastka. 


\section{References}

Anderson, L. W., \& Krathwohl, D. R. (Eds.). (2001). A Taxonomy for Learning, Teaching, and Assessing. A Revision of Bloom's Taxonomy of Educational Objectives. New York et al.: Longman.

Bednarz, S. W., \& Kemp, K. (2011). Understanding and nurturing spatial literacy. Procedia Social and Behavioral Sciences, 21, 18-23.

Bloom, B. S. (Ed.), Englehart, M. D., Furst, E. J., Hill, W. H., \& Krathwohl, D. R. (1956). The Taxonomy of Educational Objectives. The Classification of Educational Goals, Handbook I: Cognitive Domain. New York: David McKay.

BMB. (2000). Lehrpläne der AHS-Unterstufe. Retrieved from https://www.bmb.gv.at/ schulen/unterricht/lp/lp_ahs_unterstufe.html

BMBF. (2012). Geografie und Wirtschaftskunde. Richtlinien und Beispiele für Themenpool und Prüfungsaufgaben. Vienna. Retrieved from www.bmbwf.gv.at >reifepruefung _ahs_lfgw_22201

Bohlinger, S. (2007). Kompetenzen als Kernelement des Europäischen Qualifikationsrahmens. Europäische Zeitschrift für Berufsbildung, 42/43, 112-130. Retrieved from http://www.cedefop.europa.eu/etv/Upload/Information_resources/ Bookshop/491/42_de_Bohlinger.pdf

Bortz, J. (1999). Statistik für Sozialwissenschaftler (5th ed.). Berlin - Heidelberg: Springer.

Bundesgesetzblatt für die Republik Österreich. (2016). Änderung der Verordnung über die Lehrpläne der Hauptschulen, der Verordnung über die Lehrpläne der Neuen Mittelschulen sowie der Verordnung über die Lehrpläne der allgemein bildenden höheren Schulen. Geschichte und Sozialkunde/Politische Bildung. Retrieved from https://www.ris.bka.gv.at/Dokumente/BgblAuth/BGBLA_2016_II_113/BGBLA_201 6_II_113.html

Bundeszentrale für politische Bildung. (2011). Der Beutelsbacher Konsens. Retrieved from https://www.bpb.de/die-bpb/51310/beutelsbacher-konsens

Curriculum Group GW. (2020). Fachlehrplan für den Gegenstand Geographie und Wirtschaftliche Bildung. Entwurf vom. Manuscript.

Daum, E., \& Werlen, B. (2001). Geographie des eigenen Lebens. Globalisierte Wirklichkeiten. Praxis Geographie, 4, 4-9.

Department for Education. (2013). Geography programmes of study: key stage 3 National curriculum in England. Retrieved from https://assets.publishing.service.gov.uk /government/uploads/system/uploads/attachment_data/file/239087/SECONDAR Y_national_curriculum_-_Geography.pdf

Deutsche Gesellschaft für Geographie. (2014). Bildungsstandards im Fach Geographie für den Mittleren Schulabschluss mit Aufgabenbeispielen ( $8^{\text {th }}$ ed.). Bonn: Selbstverlag Deutsche Gesellschaft für Geographie. Retrieved from http://dgfg.geography-ingermany.de/wp-content/uploads/geographie_bildungsstandards.pdf

Dickel, M. (2011). Geografieunterricht unter dem Diktat der Standardisierung. Kritik der Bildungsreform aus hermeneutisch-phänomenologischer Sicht. GW-Unterricht, 123, $3-23$.

Engartner, T. (2019). Charakteristika und Perspektiven sozioökonomischer Bildung in Deutschland. Österreich Geschichte Literatur Geographie. Vol. 1: Industrie - Innovation - Region, 84-97. 
Fridrich, C. (2021). Skills in geography and economics reflected in austria's newly developed key...

Famulla, G.-E. (2014). Sozio-ökonomische versus ökonomistische Bildung. Zwei Sichtweisen auf die Beiträge der Fachtagung 'Was ist Sozioökonomie? Was ist sozioökonomische Bildung?' Universität Bielefeld - 28 September 2012. In A. Fischer \& B. Zurstrassen, B. (Eds.). Sozioökonomische Bildung (pp. 390-410). Bonn: Bundeszentrale für politische Bildung.

Famulla, G.-E. (2019). Sozioökonomische Bildung - Grundgedanken. In Autorengruppe Sozioökonomische Bildung, Was ist gute ökonomische Bildung? Leitfaden für den sozioökonomischen Unterricht (pp. 19-31). Frankfurt/M.: Wochenschau Verlag.

Field, A. P. (2009). Discovering statistics using SPSS (3rd ed.). London: Sage.

Fischer, A. \& B. Zurstrassen (Eds.) (2014). Sozioökonomische Bildung. Bonn: Bundeszentrale für politische Bildung.

Flick, U. (1995). Triangulation. In Flick, U., v. Kardorff, E., Keupp, H., v. Rosenstiel, L., \& Wolff, S. (eds.), Handbuch Qualitative Sozialforschung. Grundlagen, Konzepte, Methoden und Anwendungen, $2^{\text {nd }}$ ed. (pp. 432-434). Weinheim: Psychologie Verlags Union.

Fögele, J. (2016). From content to concept. Teaching global issues with geographical principles. European Journal of Geography, 7(1), 6-16.

Fridrich, Ch. (2013). Von der befremdlichen Persistenz der Länderkunde im Unterrichtsgegenstand Geographie und Wirtschaftskunde. GW-Unterricht, 132, 1727.

Fridrich, Ch. (2016). Basiskonzepte in Geographie und Wirtschaftskunde - ein Vorschlag für die Sekundarstufe I. Geo Graz, 59, 24-31.

Fridrich, Ch. (2018). Sozioökonomische Bildung an allgemeinbildenden Schulen der Sekundarstufe I und II in Österreich. Entwicklungslinien, Umsetzungspraxis und Plädoyer für das Integrationsfach Geographie und Wirtschaftskunde. In T. Engartner, Ch. Fridrich, S. Graupe, R. Hedtke \& G. Tafner (Eds.), Sozioökonomische Bildung und Wissenschaft. Entwicklungslinien und Perspektiven (pp. 81-108). Wiesbaden: Springer.

Fridrich, Ch. (2020a). Wirtschaft als schwieriger Themenbereich im österreichischen Geographie und Wirtschaftskunde-Unterricht? Konsequenzen für Fortbildung und Ausbildung. OpenSpaces. Zeitschrift für Didaktiken der Geographie, 01, 5-24. Retrieved from https://uni-duisburg-essen.sciebo.de/s/HYiJVEWtwelZhbV

Fridrich, Ch. (2020b): Sozioökonomische Bildung als ein zentrales Paradigma für den Lehrplan "Geographie und Wirtschaftliche Bildung" 2020 der Sekundarstufe I. GWUnterricht, 158, 21-33.

Fridrich, Ch. \& Hofmann-Schneller, M. (2017). Positionspapier 'Sozioökonomische Bildung'. GW-Unterricht, 145, 54-57.

Fritz, U., Lauermann, K., Pächter, M., Stock, M., \& Weirer, W. (2019). Kompetenzorientierter Unterricht: Theoretische Grundlagen - erprobte Praxisbeispiele. Stuttgart: UTB.

Geographical Association. (2012). Thinking Geographically. Retrieved from https://www.geography.org.uk/write/MediaUploads/Support\%20and\%20guidanc e/GA_GINCConsultation_ThinkingGeographically_NC_2012.pdf

German Society for Geography. (2014). Bildungsstandards im Fach Geographie für den Mittleren Schulabschluss mit Aufgabenbeispielen (8 ${ }^{\text {th }}$ ed.). Bonn: Selbstverlag. Retrieved from https://geographie.de/wp-content/uploads/2014/09/geographie_ bildungsstandards.pdf 
Greiner, U., Hofmann, F., Schreiner, C., \& Wiesner, C. (2020). Bildungsstandards: Kompetenzorientierung, Aufgabenkultur und Qualitätsentwicklung im Schulsystem. Münster: Waxmann.

Gryl, I. \& Jekel, T. (2012). Re-centering GI in secondary education. Towards a spatial citizenship approach. Cartographica, 47(1), 18-28.

Haarmann, M. P. (2014). Sozioökonomische Bildung - ökonomische Bildung unter der Zielperspektive der gesellschaftlichen Mündigkeit. In A. Fischer \& B. Zurstrassen (Eds.), Sozioökonomische Bildung (pp. 206-222). Bonn: Bundeszentrale für politische Bildung.

Hasse, J. (1993). Heimat und Landschaft. Zur Aktualisierung zweier Utopien. Über Gartenzwerge, Center Parks und andere Ästhetisierungen. Wien: Passagen Verlag.

Hedtke, R. (2015). Sozioökonomische Bildung als Innovation durch Tradition. GWUnterricht 140, 18-38.

Hedtke, R. (2018). Das Sozioökonomische Curriculum. Frankfurt/M.: Wochenschau Verlag.

Hinsch, S., Pichler, H., Jekel, T., Keller L., \& Baier, F. (2014). Semestrierter Lehrplan AHS, Sekundarstufe II. Ergebnis der ministeriellen Arbeitsgruppe. GW-Unterricht, 136, 5161.

Hof, A., Hürtgen, S., \& Stieger, S. (2016). Geographiedidaktische Überlegungen zu Basiskonzepten des Unterrichtsfachs GWK unter kritischem Bezug auf sozialkonstruktivistische Raumkonzepte und digitale Geomedien - ein Diskussionsbeitrag. GW-Unterricht 142/143, 127-137. Retrieved from https://dx.doi.org/10.1553/gwunterricht142/143s127

Hofmann-Schneller, M. (2011). Kompetenzerwerb im GW-Unterricht - eine neue/alte Herausforderung. GW-Unterricht, 122, 17-23.

Holloway, S., Rice, S., \& Valentine, G. (Eds.). (2003). Key concepts in geography. London: Sage. Jackson, P. (2006). Thinking Geographically. Geography, 91(3), 199-204.

Jekel, T., \& Pichler, H. (2017). Vom GW-Unterrichten zum Unterrichten mit geographischen und ökonomischen Konzepten. Zu den neuen Basiskonzepten im österreichischen GW-Lehrplan AHS Sek II. GW-Unterricht, 147, 5-15. Retrieved from https://doi.org/10.1553/gw-unterricht147s5

Klieme, E. (2004). Was sind Kompetenzen und wie lassen sie sich 'messen'? Pädagogik, 6, $10-13$.

Kuckartz, U (2014). Mixed Methods. Methodologie, Forschungsdesigns und Analyseverfahren. Wiesbaden: Springer.

Kulick, S. (2013). Geographical concept: Diversität. In M. Rolfes \& A. Uhlenwinkel (Eds.), Metzler Handbuch 2.0 Geographieunterricht. Ein Leitfaden für Praxis und Ausbildung (pp. 217-223). Braunschweig: Westermann.

Kutscha, G. (2014). Ökonomie a Gymnasien unter dem Anspruch des Bildungsprinzips Diskursgeschichtlicher Rückblick und Zielperspektiven für die sozio-ökonomische Bildung. In A. Fischer \& B. Zurstrassen (Eds.), Sozioökonomische Bildung (pp. 63-80). Bonn: Bundeszentrale für politische Bildung.

Lambert, D. (2013). Geographical Concepts. In M. Rolfes \& A. Uhlenwinkel (Eds.), Metzler Handbuch 2.0 Geographieunterricht. Ein Leitfaden für Praxis und Ausbildung (pp. 174181). Braunschweig: Westermann. 
Fridrich, C. (2021). Skills in geography and economics reflected in austria's newly developed key...

Lambert, D., \& Morgan, J. (2010). Teaching Geography 11-18: A Conceptual Approach. Maidenhead: Open University Press.

Leat, D. (1998). Thinking Through Geography (2nd ed.). London: Chris Kington Publishing.

Marsden, B. (1995). Geography 11-16: rekindling good practice. London: David Fulton.

Maude, A. (2020). The role of geography's concepts and powerful knowledge in a future 3 curriculum. International Research in Geographical and Environmental Education, 29(3). 232-243. DOI: 10.1080/10382046.2020.1749771

Mayring, P. (2000). Qualitative Inhaltsanalyse. Grundlagen und Techniken (7th ed.). Weinheim: Deutscher Studien Verlag.

Pichler, H. (2013). Kritische Kompetenzorientierung konkret. Fachdidaktische Leitgedanken für die Umsetzung einer kritisch gewendeten Kompetenzorientierung im GW-Unterricht und für die Erstellung von Aufgaben für die kompetenzorientierte Reife- und (Diplom-)Prüfung. GW-Unterricht, 130, 15-22.

Reusser, K. (2014). Kompetenzorientierung als Leitbegriff der Didaktik. Beiträge zur Lehrerinnen- und Lehrerbildung, 32(3), 325-339.

Rhode-Jüchtern, T. (2011). Diktat der Standardisierung oder didaktisches Potenzial? - Die Bildungsstandards Geographie praktisch denken. GW-Unterricht, 124, 3-14.

Rolfes, M., \& Uhlenwinkel, A. (Eds.) (2013). Metzler Handbuch 2.0 Geographieunterricht. Ein Leitfaden für Praxis und Ausbildung. Braunschweig: Westermann.

Sander, W. (2010). Wissen im kompetenzorientierten Unterricht - Konzepte, Basiskonzepte, Kontroversen in den gesellschaftswissenschaftlichen Fächern. Zeitschrift für Didaktik der Gesellschaftswissenschaften, 1, 42-66.

Schank, C., \& Lorch, A. (2015). Economic citizenship and socio-economic rationality as foundations of an appropriate economic education. Journal of Social Science Education, 14(1), 56-65. DOI 10.2390/ jsse-v14-i1-1271

Schultze, A. (1996). Vierter Problemkreis: Länderkunde oder Allgemeine Geographie? Regionale oder Thematische Geographie? In A. Schultze (Ed.), 40 Texte zur Didaktik der Geographie (pp. 26-32). Gotha: Justus Perthes.

Sitte, C. (1989). Entwicklung des Unterrichtsgegenstandes Geographie, Erdkunde, Geographie und Wirtschaftskunde an den allgemeinbildenden Schulen (APS und AHS) in Österreich nach 1945. Dissertation an der Universität Wien.

Sitte, C. (2001). Der GW-Lehrplan 1985/86 - Neue Zielsetzungen und Inhalte. In W. Sitte \& H. Wohlschlägl (Eds.), Beiträge zur Didaktik des „Geographie und Wirtschaftskunde“Unterrichts (pp. 223-247). Vienna: Institut für Geographie und Regionalforschung der Universität Wien.

Sitte, W. (1975). Das Unterrichtsfach „Geographie und Wirtschaftskunde“ im Spannungsfeld neuer Entwicklungen. In W. Sitte \& H. Wohlschlägl (Eds.), Schulgeographie im Wandel. Beiträge zur Neugestaltung des Geographieunterrichts an den Allgemeinbildenden Höheren Schulen (pp. 11-43). Vienna: Verlag A. Schendl.

Sitte, W. (2001). Geographie und Wirtschaftskunde (GW) - Entwicklung und Konzept des Unterrichtsfachs. In W. Sitte \& H. Wohlschlägl (Eds.), Beiträge zur Didaktik des „Geographie und Wirtschaftskunde-Unterrichts (pp.157-169). Wien: Institut für Geographie und Regionalforschung der Universität Wien.

Tafner, G. (2015). Reflexive Wirtschaftspädagogik. Wirtschaftliche Erziehung im ökonomisierten Europa. Eine neoinstitutionelle Dekonstruktion des individuellen und 
kollektiven Selbstinteresses. Humboldt-Universität zu Berlin: Habilitationsschrift. Detmold: EUSL.

Taylor, L. (2008). Key concepts and medium-term planning. Teaching Geography, 33(2), 5054.

Uhlenwinkel, A. (2013a). Geographical Concepts als Strukturierungshilfe für den Geographieunterricht. Ein international erfolgreicher Weg zur Erlangung fachlicher Identität und gesellschaftlicher Relevanz. Geographie und ihre Didaktik, 1., 18-43.

Uhlenwinkel, A. (2013b). Geographical concept: Place. In M. Rolfes \& A. Uhlenwinkel (Eds.), Metzler Handbuch 2.0 Geographieunterricht. Ein Leitfaden für Praxis und Ausbildung (pp. 182-188). Braunschweig: Westermann.

Uhlenwinkel, A. (2013c). Geographical concept: Space. In M. Rolfes \& A. Uhlenwinkel (Eds.), Metzler Handbuch 2.0 Geographieunterricht. Ein Leitfaden für Praxis und Ausbildung (pp. 189-195). Braunschweig: Westermann.

Uhlenwinkel, A. (2013d). Geographical concept: Maßstab. In M. Rolfes \& A. Uhlenwinkel (Eds.), Metzler Handbuch 2.0 Geographieunterricht. Ein Leitfaden für Praxis und Ausbildung (pp. 196-202). Braunschweig: Westermann.

Uhlenwinkel, A. (2013e). Geographical concept: Vernetzung. In M. Rolfes \& A. Uhlenwinkel (Eds.), Metzler Handbuch 2.0 Geographieunterricht. Ein Leitfaden für Praxis und Ausbildung (pp. 210-216). Braunschweig: Westermann.

Ulrich, P. (2008). Integrative Wirtschaftsethik. Grundlagen einer lebensdienlichen Ökonomie. Bern - Stuttgart - Wien: Haupt Verlag.

Vielhaber, C. (2008). Standards und/oder Kompetenzen im GW-Unterricht? GW-Unterricht, 110, 1-6.

Wald, F. (2013). Geographical concept: Wahrnehmung und Darstellung. In M. Rolfes \& A. Uhlenwinkel (Eds.), Metzler Handbuch 2.0 Geographieunterricht. Ein Leitfaden für Praxis und Ausbildung, (pp. 224-229). Braunschweig: Westermann.

Weichhart, P. (1996). Die Region - Chimäre, Artefakt oder Strukturprinzip sozialer Systeme? In G. Brunn (Ed.), Region und Regionsbildung in Europa: Konzeptionen der Forschung und empirische Befunde. Wissenschaftliche Konferenz, Siegen 10.-11. Oktober 1995 (pp. 25-43). Baden-Baden: Nomos Verlagsgesellschaft.

Weinert, F. E. (2001). Leistungsmessung in Schulen. Weinheim: Beltz.

Werlen, B. (1995). Sozialgeographie alltäglicher Regionalisierungen. Vol. 1: Zur Ontologie von Gesellschaft und Raum (= Erdkundliches Wissen, 116). Stuttgart: Steiner Verlag.

Werlen, B. (1997). Gesellschaft, Handlung und Raum: Grundlagen handlungstheoretischer Sozialgeographie. Stuttgart: Franz Steiner Verlag.

Wienecke, M. (2013). Geographical concept: Wandel. In M. Rolfes \& A. Uhlenwinkel (Eds.), Metzler Handbuch 2.0 Geographieunterricht. Ein Leitfaden für Praxis und Ausbildung (pp. 203-209). Braunschweig: Westermann

\section{Biographical Statement}

Christian FRIDRICH is Professor Doctor at the Vienna University of Teacher Education and teaches at the University of Graz and the University of Vienna. He is a founding member and co-editor of the two series "Socio-Economic Education and Science" and "Critical Consumer Research" at Springer and the series "Research Perspectives" at LIT. Furthermore, he is editor of the journal "GW-Unterricht" at the publishing house of the Austrian Academy of Sciences and several textbook series and founding member of the "Gesellschaft für 
sozioökonomische Bildung und Wissenschaft" ["Association for socioeconomic education and research"]. In addition, he is head of the Austria-wide specialist group "Geographical and Socio-economic Education" (GESÖB) at the Austrian Geographical Society. Main areas of work and research: Didactics of Geography and Economics; theory, didactics and implementation practice of economics education; life worlds, pre-concepts and conceptual growth; visual literacy, data visualization and image pedagogy. 